\title{
Que estratégia de desenvolvimento seguir? \\ O Debate Desenvolvimentista Brasileiro no Século XXI
}

\section{Which development strategy should Brazil choose? The Brazilian Developmentalist Debate in the 21st Century}

\author{
Arthur Gomes Moreira* \\ Marcelo Arend**
}

\begin{abstract}
Resumo: Forma-se na primeira década do século XXI um novo debate entre diferentes estratégias de desenvolvimento para o Brasil. Se no intervalo entre 1930 e 1980 havia uma ideologia intervencionista, com características e proporções distintas, que marcou a política econômica nacional, os 20 anos que sucederam esse interregno foram marcados pelo afastamento do Estado dos objetivos de desenvolvimento econômico para a superação do atraso. Constatado mais uma vez que esses objetivos não podem ser alcançados sem a participação direta do Estado, fator imprescindível, mas também longe de ser suficiente para lograr a superação do atraso, diferentes correntes se posicionam e elaboram material teórico-ideológico para estruturar estratégias consistentes para o país. O objetivo deste artigo é enumerar, contrastar e propor maior atenção sobre certos pontos que foram menos discutidos pelos defensores dessas correntes.
\end{abstract}

Palavras-chave: Estratégias desenvolvimentistas. Desenvolvimentismo. Planejamento econômico.

Abstract: In the last decade a new debate between different development strategies for Brazil took place. Taken that between 1930 and 1980 an interventionist ideology with different characteristics and proportions marked the national economic policy, the following twenty years were marked by a distancing between the State and the goals of catching up. Noted again that these goals can not be achieved without direct participation of the State, indispensable factor however far from sufficient to promote the catching up, different groups are politically positioning themselves and elaborating theoretical and ideological material to structure consistent strategies for the country. The purpose of this article is to enumerate, contrast and propose greater attention on certain points that were less discussed by the proponents of these strategies.

Keywords: Developmentalist strategies. Developmentalism. Economic planning.

JEL Classification: B50; O11; O21.

Mestrando em Economia pela Universidade Federal de Santa Catarina (UFSC). E-mail: arthurgmoreira@gmail.com

** Professor do Departamento de Economia e Relações Internacionais da Universidade Federal de Santa Catarina (UFSC).E-mail: marcelo.arend@ufsc.br 


\section{Introdução}

A retomada do tema do desenvolvimentismo vem ganhando força nos últimos anos após um período em que a teoria de inclinação neoclássica dominou o cenário teórico na economia. Também, desde a década de 1990, no âmbito da política econômica seguida pelos Estados Nacionais, a perspectiva do mainstream econômico que advogava pelas reformas neoliberais vem sendo desafiada pela crescente instabilidade dos mercados financeiros e por evidências de que os países que mais aceleraram seu crescimento foram os que não seguiram as recomendações do Consenso de Washington (BRESSER-PEREIRA, 2012b). ${ }^{1}$ Em relação ao Brasil, a presença mais destaca da intervenção estatal na dinâmica econômica nos anos 2000 contribuiu para uma taxa média de crescimento econômico mais elevada e para a melhora nos indicadores de distribuição de renda, retomando, por conseguinte, o debate sobre estratégias nacionais de desenvolvimento. ${ }^{2}$

Aceita-se que o Estado tem papel fundamental no processo de desenvolvimento econômico, logo o debate contemporâneo está posto em certas estratégias claras e distintas que estão sendo discutidas pela academia e tendem a integrar certos planos de governo e diretrizes de política econômica. As principais estratégias de desenvolvimento para o futuro da nação são rapidamente listadas nesta introdução e, ao longo do artigo, contrastadas e analisadas sob a ótica da necessidade de mudanças institucionais e tecnológicas. ${ }^{3}$

A primeira corrente em destaque, encabeçada pelo ex-ministro Luiz Carlos Bresser-Pereira, e por José Luis Oreiro, intitula-se novo desenvolvimentismo. Os novos desenvolvimentistas realizam estudos conjuntos, sendo muitos publicados em revistas de excelência do Brasil e do exterior, além de se posicionarem sobre temas relevantes em jornais midiáticos, blogs e páginas pessoais. Seus principais representantes podem ser identificados através do grupo de pesquisa do CNPq intitulado "Macroeconomia estruturalista do desenvolvimento". Alegando posicionarem-se sob um "novo" marco teórico em construção, afirmam que o principal

$1 \quad$ No final dos anos 1990, Fiori (1999) já chamava a atenção para o fato de que a discussão sobre o desenvolvimento tinha voltado à tona, uma vez que esteve em baixa durante os anos de neoliberalismo e que isso era reflexo da gravidade da crise asiática de 1997-1998, da impotência de políticas ortodoxas em lidar com a nova dinâmica do sistema financeiro e da observação de que as diferenças entre os países centrais e os periféricos aumentaram. Esses pontos indicaram, segundo Fiori (1999), que o capitalismo global, com seus mercados desregulados e globalizados, não daria conta do projeto de desenvolvimento dos países nem da convergência entre eles.

Como bem aponta Carneiro (2012), após a primeira metade dos anos 2000, com o fracasso das perspectivas da ideologia neoliberal para a promoção do desenvolvimento dos países periféricos, principalmente se comparadas ao modelo de expansão econômica da Ásia, que não adotou tais políticas, emergiram novas correntes interpretativas do desenvolvimento brasileiro.

3 A demonstração da inclinação partidária das estratégias e de alguns de seus autores que este artigo procura aclarar não tem a intenção de esvaziar o debate acadêmico, mas apenas mostrar a importância que tomam os textos teóricos no sentido de implicação prática de política econômica da estratégia, que, por exemplo, pode sair vencedora do pleito de 2014 para o Executivo federal. 
ponto de estrangulamento do desenvolvimento econômico está do lado da demanda, interna e externa, devido a duas tendências estruturais que a restringem. No âmbito interno, os salários cresceriam menos do que a produtividade. O gargalo quanto ao mercado externo decorre da tendência à sobreapreciação cíclica da taxa de câmbio, que reduz a competitividade exportadora da nação e, por conseguinte, seu crescimento.

A segunda corrente ultimamente vem sendo denominada de social-desenvolvimentista. Segundo Bastos (2012, p. 793), ao contrário do novo desenvolvimentismo, essa corrente "[...] não se limita a um corpo de ideias sistematizado academicamente [...]", todavia “[...] parece ter usufruído de crescente influência nos governos petistas (muito embora não se restrinja a militantes ou simpatizantes petistas)". Correndo o risco de generalização, talvez esse grupo possa ser representado pelos integrantes da Rede Desenvolvimentista (RedeD), da qual se destacam Ricardo Carneiro, André Biancarelli e Ricardo Bielschowsky. ${ }^{4}$ Reivindicam uma estratégia nacional não voltada para fora, mas ancorada no dinamismo do mercado nacional, com valorização de salários e distribuição de renda.

Além das duas correntes arroladas, que se autointitulam de desenvolvimentistas, avalia-se neste artigo uma terceira que vem despontando não só no cenário acadêmico nacional, mas principalmente na mídia: os pesquisadores do Instituto de Estudos de Política Econômica/Casa das Garças (Iepe/CdG). Edmar Bacha, Regis Bonelli, Gustavo Franco e Samuel Pessôa vêm se destacando nesse grupo através de artigos acadêmicos e críticas na mídia ao atual governo. Em linhas gerais, sugerem que a baixa participação da economia brasileira no comércio internacional tem relações com sua reduzida taxa de crescimento econômico e elevada taxa de inflação. Defendem que, se no período 2004-2011 a conjuntura externa era favorável (altos preços de commodities e bom fluxo de capitais estrangeiros), a situação a partir de 2011 modificou-se e trouxe à tona a "doença brasileira" - elevada inflação com baixo crescimento. A proposta é que deveria haver mais "exportabilidade" da economia, ou seja, maior integração nas cadeias internacionais de valor.

A proposta do artigo é principalmente contrastar essas três estratégias elencadas. Para isso, utiliza-se o estudo de Fonseca (2014), que construiu a definição do conceito de desenvolvimentismo, de modo a deixar mais claro o debate brasileiro sobre o tema. Valendo-nos dessa definição, surge a questão: as estratégias propostas atualmente pela academia podem ser classificadas como desenvolvimentistas? Para respondê-la, é necessário fazer uma análise detalhada de cada uma comparando-as com o núcleo comum de atributos que estruturam o conceito - projeto nacional, intervenção consciente estatal e industrialização.

$4 \quad$ A Rede é resultado de uma parceira de três instituições: o Centro de Estudos de Conjuntura e Política Econômica (Cecon) da Unicamp, o Centro de Gestão e Estudos Estratégicos (CGEE) do MCTI e o Instituto de Pesquisa Econômica Aplicada (Ipea) da Secretaria de Assuntos Estratégicos da Presidência da República. 
Este artigo está estruturado em quatro seções, além desta introdução: a segunda analisa as três principais correntes que pensam diferentes estratégias para o país; a terceira as compara e as coloca diante da definição do termo desenvolvimentismo; a quarta avalia suas possibilidades e faz sugestões às estratégias vigentes, a partir de elementos constituintes de uma estratégia de desenvolvimento para o século XXI; e a quinta e última faz algumas considerações finais sobre o assunto.

\section{As Atuais Estratégias para o Brasil}

Segundo Bresser-Pereira (2012c), a história do Brasil independente pode ser dividida em três ciclos políticos: Estado e integração territorial, que cobre o período imperial, o ciclo nação e desenvolvimento, que, após o período de transição da República Velha, durou de 1930 até o declínio da ditadura civil-militar, e o ciclo democracia e justiça social, em voga desde final dos anos 1970. O último ciclo rejeitaria as ideias do nacional-desenvolvimentismo e aceitaria a dependência como fato sociológico e econômico inevitável. O autor afirma que, a partir da década de 1970, a continuidade da industrialização estaria garantida através de uma associação com o capital estrangeiro e que os problemas internos à nação a serem resolvidos seriam o autoritarismo militar e a desigualdade. ${ }^{5}$

Nesse sentido, Bresser-Pereira (2007) sugere que, nos anos 1980, o ideário presente nos partidos políticos dominantes (PMDB, PT e PSDB) do Brasil pós-redemocratização partia do pressuposto de que o desenvolvimento econômico estava garantido, além de serem partidos para os quais a ideia de nação estava quase ausente. Segundo ele (2007, p. 257),

[...] tendo nascido de um ciclo de ideias e valores que negava a possibilidade de existência de uma "burguesia nacional", e portanto de uma Nação, e que supunha o desenvolvimento econômico como assegurado graças à poupança externa ou às empresas multinacionais, esses partidos não tinham a idéia de Nação. Desta forma, não opuseram grande resistência à nova hegemonia que vinha do Norte no bojo da grande onda neoliberal.

Segundo Cordeiro (2014), essa dinâmica político-social na qual estaria assentado o ciclo democracia e justiça social foi determinada por quatro fatores: a) as disputas ideológicas sobre o modelo de desenvolvimento dos anos 1970, que colo-

$5 \quad$ Bresser-Pereira critica duramente a tese de que não haveria uma burguesia nacional no Brasil, aceita pelas teorias da superexploração e da dependência associada. Para ele, o Brasil, desde aquele tempo, caracteriza-se por ser uma sociedade nacional dependente, que alterna momentos de maior dependência com outros de maior nacionalismo. "Quanto mais dependente e menos nacional forem as elites nacionais, mais o país estará próximo da semi-estagnação. Quanto menos dependente e mais nacional, maior será a probabilidade de um verdadeiro desenvolvimento" (BRESSER-PEREIRA, 2012c, p. 28). 
caram frente a frente o antagonismo da teoria da dependência associada diante da teoria da superexploração imperialista, contribuíram para o enfraquecimento do modelo nacional-desenvolvimentista e a supremacia da visão do desenvolvimento associado; b) a entrada de novos atores - civis e não mais diretamente ligados à elite do país - na discussão dos rumos do desenvolvimento; c) a ampliação do significado do desenvolvimento, que expandiu seus limites economicistas e deu um tom multidisciplinar à discussão; e d) a crescente preocupação com um desenvolvimento sustentável e os limites ambientais de um crescimento irresponsável. ${ }^{6}$

A relativa estagnação econômica e a extrema vulnerabilidade externa da economia brasileira nos anos 1990 estariam dessa forma atreladas à adoção de uma estratégia de crescimento com poupança externa. Entretanto, desde meados dos anos 2000, o Brasil estaria recuperando a ideia de nação (BRESSER-PEREIRA, 2012c). Para o autor, haveria uma volta ao desenvolvimentismo, e talvez esteja se produzindo uma síntese entre os dois últimos ciclos políticos: nação e desenvolvimento e democracia e justiça social.

Cordeiro (2014) analisa o debate contemporâneo sobre o desenvolvimento e se pergunta sobre a duração do atual ciclo no qual o desenvolvimento brasileiro estaria inserido (ciclo de democracia e justiça social). Segundo o autor, existiriam atualmente cinco projetos concorrentes de desenvolvimento: a) o projeto de justiça social, hegemônico nesse ciclo, sob a batuta do PT, vem desde a eleição de Lula e em certa medida fez frente aos desafios das crises dos anos 1980 e da onda neoliberal dos anos 1990; b) o novo desenvolvimentismo, que, para Cordeiro (2014, p. 243), ainda não apresenta uma coalizão definida em torno de seu projeto, mas para este estudo já mostra vinculações inclusive políticas, conforme é exposto no decorrer do artigo; c) o projeto de desenvolvimento sustentável, que estaria sendo defendido mais em debates teóricos e empíricos por novos atores e não teria presença política definida ainda. Esses três seriam os projetos reformistas do desenvolvimento nacional. Há ainda um conservador, que é o projeto neoliberal, que se preocupa com o livre-mercado e a segurança jurídica das atividades

6 É interessante notar como todos esses quatro fatores nos remetem a Celso Furtado. 1) A crítica das teorias da dependência relegou ao segundo plano suas ideias nacional-desenvolvimentistas e fez cair em descrença, nos anos do "milagre econômico" brasileiro, seu alerta para a tendência de estagnação e de crise do balanço de pagamentos e crise inflacionária das economias latino-americanas, que vieram a ser confirmadas nos anos 1980-90 (PAULA, 2013). 2) A entrada da sociedade civil na discussão sobre os rumos do país é, para Furtado (1978), fator chave na descoberta dos fins últimos do desenvolvimento esperado. 3) A abertura do escopo de análise da Economia e da economia brasileira é uma característica marcante dos escritos de Furtado a partir do entendimento de que a teoria do desenvolvimento econômico não era capaz de lidar com a realidade dos países periféricos. Foi nessa época, principalmente na década de 1970, que Furtado passou a colocar a cultura como tendo papel central na dinâmica dos países (CUNHA; BRITTO, 2011). 4) Também estava presente em seus escritos (FURTADO, 1974; 1978) a preocupação com a manutenção da vida no planeta, o que o levou a fazer um alerta sobre o "mito do desenvolvimento econômico", que explicava a impossibilidade de os países emergentes conseguirem um dia igualar o padrão de consumo dos países ricos diante da escassez de recursos físicos do planeta. 
econômicas, e um revolucionário, que é o projeto socialista. Este estaria mais enfraquecido desde o colapso da União Soviética e alguns de seus pensadores então passaram a incluir tendências de atuação através do sistema democrático. O Quadro 1 abaixo resume as principais características dos projetos de desenvolvimento contemporâneos.

Quadro 1 - O espectro dos projetos políticos de desenvolvimento em disputa no Brasil contemporâneo

\begin{tabular}{|c|c|c|c|c|c|}
\hline \multirow{2}{*}{ (A) } & \multirow{2}{*}{$\begin{array}{l}\begin{array}{c}\text { Revolu- } \\
\text { cionários }\end{array} \\
\text { Socialismo }\end{array}$} & \multicolumn{3}{|c|}{ Reformistas } & \multirow{2}{*}{$\begin{array}{c}\text { Conserva- } \\
\text { dores }\end{array}$} \\
\hline & & $\begin{array}{l}\text { Justiça } \\
\text { Social }\end{array}$ & $\begin{array}{c}\text { Desen- } \\
\text { volvimento } \\
\text { Sustentável }\end{array}$ & $\begin{array}{c}\text { Novo } \\
\text { Desenvolvi- } \\
\text { mentismo }\end{array}$ & \\
\hline (B) & $\begin{array}{l}\text { Internaciona- } \\
\text { lismo }\end{array}$ & $\begin{array}{c}\text { Solidarieda- } \\
\text { de Sul-Sul }\end{array}$ & $\begin{array}{c}\text { Ambienta- } \\
\text { lismo }\end{array}$ & $\begin{array}{c}\text { Nacional } \\
\text { Dependen- } \\
\text { te }\end{array}$ & $\begin{array}{l}\text { Globaliza- } \\
\text { ção }\end{array}$ \\
\hline (C) & Estatismo & $\begin{array}{l}\text { Bem-Estar } \\
\text { Social/ Re- } \\
\text { distributivo }\end{array}$ & $\begin{array}{l}\text { Economia } \\
\text { Verde }\end{array}$ & $\begin{array}{l}\text { Keynesianis- } \\
\text { mo Indus- } \\
\text { trialista }\end{array}$ & $\begin{array}{l}\text { Livre Mer- } \\
\text { cado }\end{array}$ \\
\hline (D) & $\begin{array}{c}\text { Proletariado/ } \\
\text { Trabalhado- } \\
\text { res }\end{array}$ & $\begin{array}{c}\text { Cidadãos/ } \\
\text { Sociedade } \\
\text { Civil }\end{array}$ & $\begin{array}{c}\text { Ser Hu- } \\
\text { mano/Meio } \\
\text { Ambiente }\end{array}$ & $\begin{array}{c}\text { Empre- } \\
\text { sariado/ } \\
\text { Burguesia } \\
\text { Industrial }\end{array}$ & $\begin{array}{l}\text { Burguesia } \\
\text { Rural/ Ren- } \\
\text { tista }\end{array}$ \\
\hline (E) & $\begin{array}{c}\text { Populismo } \\
\text { Democrático }\end{array}$ & $\begin{array}{l}\text { Democracia } \\
\text { Participativa }\end{array}$ & $\begin{array}{l}\text { Democra- } \\
\text { cia Ética }\end{array}$ & $\begin{array}{l}\text { Democracia } \\
\text { Burocrática }\end{array}$ & $\begin{array}{c}\text { Democracia } \\
\text { Representa- } \\
\text { tiva }\end{array}$ \\
\hline$(F)$ & Igualdade & Cidadania & Equilíbrio & $\begin{array}{l}\text { Cresci- } \\
\text { mento }\end{array}$ & Segurança \\
\hline
\end{tabular}

Fonte: Cordeiro (2014).

Nota: (A) Projeto de desenvolvimento; (B) Visão de Mundo; (C) Modelo Econômico; (D) Ator preponderante (E) Sistema político; (F) Condição Sine Qua Non.

Segundo a análise de Cordeiro (2014), dentre os cinco projetos de desenvolvimento, apenas três estão atualmente estruturados: justiça social, novo desenvolvimentismo e neoliberalismo. A perspectiva do socialismo mostra-se enfraquecida e a do desenvolvimento sustentável é incorporada ao discurso dos demais projetos de forma marginal. Vale destacar que o autor considera que o atual ciclo promove ganhos, mas ainda não estaria consolidado. Portanto, a entrada de outros fatores, para além da economia, influenciando o debate sobre o desenvolvimento, vem ganhando cada vez mais força. Nessa linha, Mollo (2014) aprova os ideais desenvolvimentistas contemporâneos, mesmo entendendo-os como uma busca reformista, que não defenderá a transformação do capitalismo para um modo de 
produção mais justo. Para ela, os avanços que as correntes pós-keynesianas almejam convergem com as propostas marxistas - na linha de autores como Poulantzas e Jessop -, pois, ao buscarem melhorar a posição dos trabalhadores na relação capital-trabalho, dão condições para sua melhor organização e preparação para a autogestão da sociedade transformada.

Nesse sentido, e seguindo a tipologia dos projetos nacionais de Cordeiro (2014), hoje o pensamento desenvolvimentista estaria estruturado em duas grandes vertentes, o social-desenvolvimentismo (justiça social), ou "desenvolvimentismo distributivo orientado pelo Estado", como prefere Bastos (2012), e o novo desenvolvimentismo, ou "desenvolvimentismo exportador orientado pelo setor privado". Uma terceira estratégia econômica para o país, oriunda da linha de pensamento neoliberal defendida na Casa das Garças/FGV, corre por fora e também busca se fortalecer. As próximas subseções buscam exatamente analisar esses três projetos contemporâneos.

\subsection{O Social-Desenvolvimentismo}

O social-desenvolvimentismo enfatiza, sobretudo, a capacidade de a economia brasileira crescer sob o dinamismo de seu mercado interno, com atuação forte do Estado na distribuição de renda e orientação dos investimentos (BASTOS, 2012). Seus principais defensores na academia recomendam muito mais continuidade do que ruptura com o modelo de crescimento instituído a partir de meados da década de 2000. Elevação dos salários, ampliação do gasto social, fortalecimento de empresas e de bancos de investimento estatais, políticas industriais setoriais, microcrédito, habitação popular e erradicação da pobreza são algumas das principais políticas que deveriam ser aprofundadas com a presença marcante do Estado na sua condução. A preocupação com o desenvolvimento brasileiro se desdobra para outros temas associados, como os do desenvolvimento latino-americano, da integração regional com o fortalecimento do Mercosul, das relações Sul-Sul e dos Brics. Essa estratégia tem sido em grande monta a utilizada pelo atual governo federal, principalmente no segundo mandato de Luiz Inácio Lula da Silva e no governo Dilma Rousseff.

Devido à falta de um corpo de ideias sistematizadas em textos acadêmicos, considera-se que o ensaio que explicita a estratégia social-desenvolvimentista é o trabalho de Bielschowsky (2012), no qual ele estrutura três frentes de expansão da renda nacional. Em grande medida, as três frentes das quais discorre o autor resultam de um esforço de síntese para caracterizar a dinâmica nacional ocorrida a partir da segunda metade dos anos 2000 e a necessidade de ajustes estruturais para a garantia de um desenvolvimento sustentado de longo prazo. Tais frentes derivam de características singulares do país que deveriam ser aproveitadas para 
promover o desenvolvimento. São elas: a) o amplo (e com grande capacidade de expansão) mercado interno de consumo de massa; b) a demanda interna e externa pelos abundantes recursos naturais do país; c) e a demanda estatal e privada por investimentos em infraestrutura (tanto econômica quanto social). O autor defende que, se a essa demanda corresponder um investimento vigoroso, nossa economia poderá crescer bastante por algumas décadas e de modo ainda mais amplo se aproveitados os dois turbinadores desse investimento: os processos inovantes e os encadeamentos produtivos.

O primeiro motor se vale de um círculo virtuoso que se inicia com forte expansão do mercado de consumo de massa provocando expansão dos investimentos. Assim, através do aumento da relação capital-trabalho, do conhecimento e aprendizado, da inovação e de economias de escala, elevam-se a competitividade e a produtividade. Esta, então, se transmite para lucros e para salários e transforma-se em consumo. Tal modelo de produção e consumo de massa exige que se realize no país parte importante dos encadeamentos produtivos - para que não aconteça, como previne o autor, de haver "consumo de massa no Brasil e produção em massa na China”. Reconhece-se que isso é essencial para o Brasil não correr riscos de desindustrialização e estrangulamento no balanço de pagamentos a médio ou longo prazo, o que parece, em certa medida, já acontecer.7

O segundo motor se origina da alta demanda externa, principalmente asiática, por recursos naturais, o que pode gerar ganhos na renda brasileira se as atividades baseadas nesses recursos promoverem emprego, progresso técnico e bem-estar social, isto é, se tais atividades conseguirem se consolidar como mais do que apenas exportação de produtos de baixo valor agregado para fora. Nesse sentido, o autor cita Pérez (2010) como um bom exemplo a se seguir no uso de recursos naturais como estratégia de desenvolvimento. ${ }^{8}$ Bielschowsky (2012) orienta ainda

7 Segundo o Banco Central do Brasil (2015a), o saldo em transações correntes vem caindo vertiginosamente desde 2007, após um período que conseguiu obter superávits, entre 2003 e 2007, quando as commodities apresentaram alta nos preços. O Brasil registrou déficit em transações correntes recorde de 81,374 bilhões de dólares em 2013, não sendo financiado pelos investimentos estrangeiros diretos (IED) pela primeira vez desde 2001, deixando mais evidente a deterioração das contas externas do país.

8 Para Carlota Pérez (2010), apesar da elevação dos preços de commodities a partir dos anos 2000 ter impulsionado um ritmo maior de crescimento para a América Latina, as capacidades tecnológicas não cresceram no mesmo ritmo e chegam a estar relativamente mais desiguais que nos anos 1970. Enquanto parece ser consenso que certos países asiáticos têm vantagens em indústrias intensivas em mão de obra e a América Latina tem vantagens em indústrias baseadas em recursos naturais, estas poderiam permitir, segundo a autora, especializações diferenciadas. É preciso estar atento à oportunidade que a alta dos preços nos proporciona, para que não seja desperdiçada com crescimento superficial e incremento de importações para o consumo. Para a autora, existe no cenário atual uma janela na qual os países latino-americanos poderiam adquirir capacidades em indústrias ainda baseadas em recursos naturais, mas voltadas para a biotecnologia e a ciência dos materiais, de modo a criar vantagens em áreas que provavelmente estarão na próxima revolução tecnológica, como essas citadas, além de nanotecnologia e bioeletrônica. Haveria, assim, uma migração gradual para a produção de bens com maior valor agregado, diferenciada 
que é necessário que os bens de capital e insumos utilizados sejam preponderantemente produzidos no Brasil, podendo então a economia nacional se beneficiar dos encadeamentos produtivos e da inovação. Essa parece ser uma questão-chave para os sociais-desenvolvimentistas, pois remete a temas como a defesa da indústria e política industrial, adensamento produtivo e, até mesmo, substituição de importações. É destacada, ainda, a preocupação com algumas ameaças claras a esse projeto, como a compra de terra e de outros fatores por outros países, a pressão sobre o meio ambiente e a absorção de ganhos com os recursos pelo setor privado ou por "interesses públicos menores", como lucros para acionistas ou ganhos com impostos em vez de royalties.

O último motor do desenvolvimento é o investimento em infraestrutura por sua característica de fazer girar muitos recursos, empregos e externalidades para toda a economia. Através de áreas como transporte, energia elétrica, habitação e saneamento, telecomunicações, e também via Petrobras, o investimento deve ser constante e firme, sendo seguido pelo investimento autônomo. Mais uma vez os benefícios vão além dos ganhos que a frente da infraestrutura fornece, pois, se esta for bem utilizada, eles se estendem pela economia através encadeamentos e inovação.

Quanto aos dois turbinadores dos três motores, a inovação refere-se a novos processos e produtos e os investimentos em encadeamentos produtivos a setores tradicionais. Apesar de ressaltar que "a inovação tecnológica tem um papel fundamental”, diante da constatação de que as empresas do país não são inovadoras, o autor descarta sua função de base da estratégia atual de desenvolvimento, o que não significaria "ficar parado em matéria de inovação e investimentos em segmentos selecionados de alta intensidade tecnológica” (BIELSCHOWSKY, 2012, p. 744), mas dar a ela o papel de incrementar as três frentes de expansão. Ao explicar o peso do segundo turbinador dessa estratégia, em que os encadeamentos produtivos devem fortalecer-se, ou mesmo serem inaugurados (nas novas atividades do pré-sal, por exemplo), relativiza-se mais uma vez o processo inovador em comparação com políticas industriais e demandas do governo no intuito de gerar investimentos e competitividade. ${ }^{9}$

no sentido de atender demandas específicas e estabelecendo potentes redes de inovação com participação de empresas e universidades, tanto nacionais quanto externas.

“[...] as decisões de investimento inclinam-se a depender menos de inovações tecnológicas do que de outros incentivos à rentabilidade como taxas de câmbio mais favoráveis, demanda de governo e outras políticas industriais que possam contribuir para a reconstituição da competitividade perdida" (BIELSCHOWSKY, 2012, p. 731). 


\subsection{O Novo Desenvolvimentismo}

A motivação, para Bresser-Pereira e os demais pesquisadores do grupo Macroeconomia Estruturalista do Desenvolvimento elaborarem uma nova estratégia de desenvolvimento, vem dos desafios trazidos pelo atual estágio da economia brasileira. Afirma Bresser-Pereira (2012a) que esse desafio não é mais iniciar a industrialização ou a revolução industrial brasileira, mas enfrentar os desafios da desindustrialização provocada pelas políticas neoliberais, distinguir política macroeconômica de política industrial, mostrar à sociedade uma política macroeconômica que combine estabilidade de preços e uma financeira com crescimento e fazer frente não mais a uma oligarquia do setor primário-exportador, mas aos capitalistas rentistas e aos interesses estrangeiros no mercado interno. Para o autor, a instituição básica para o crescimento econômico não é a garantia dos direitos de propriedade e de contratos (como apregoado pela Nova Economia Institucional), mas sim uma estratégia nacional para o desenvolvimento.

Essa nova proposta ganha força no cenário acadêmico e político nacional, mas não é consenso entre os economistas, mesmo os heterodoxos. Diante disso, Bresser-Pereira propõe que o novo desenvolvimentismo seja a bandeira da linha desenvolvimentista brasileira atual, mesmo com diferentes posições teóricas e de política econômica, na medida em que busque mais do que apenas a adoção do termo, mas principalmente a criação de uma coalizão nacional que faça frente aos interesses escusos e à retórica dos economistas e seus "modelos matemáticos idealistas", ao mesmo tempo que trabalhe a consistência teórica. ${ }^{10}$

Bresser-Pereira chama de novo desenvolvimentismo a estratégia nacional de desenvolvimento aplicada à realidade periférica da América Latina e de macroeconomia estruturalista do desenvolvimento a atual teorização mais sistemática que se faz do estruturalismo no campo da macroeconomia do desenvolvimento, para tratar dos países atrasados, de renda média, mas já industrializados (no caso de países mais pobres seria necessário fazer algumas adaptações). Essa estratégia está sistematizada no livro Globalização e competição (2010) e no artigo "Macroeconomia estruturalista do desenvolvimento" (2010), com coautoria de Paulo Gala, além de artigos, sobretudo, produzidos por Oreiro e outros sobre crescimento,

10 Identificam-se nesta pesquisa duas tendências entre os principais expoentes novo desenvolvimentistas: em primeiro lugar, a linha defendida por Bresser-Pereira é a de conciliação teórica com o social-desenvolvimentismo. A esse respeito, Bresser-Pereira (2012d) procura aproximação com o social-desenvolvimentismo. Respostas a favor da aproximação foram de André Biancarelli, Pedro Rossi e Pedro Paulo Bastos. Em outra linha, José Luis Oreiro procura vincular o novo desenvolvimentismo à questão política. Os pontos defendidos por essa estratégia cada vez mais apontam para sua incorporação pela chapa concorrente à presidência de Campos e Marina Silva. José Luis Oreiro, expoente do novo desenvolvimentismo, recentemente escreveu artigo de política econômica para essa aliança. Segundo ele, foi "[...] produzido a pedido da liderança do PPS com o intuito de embasar as discussões a respeito da elaboração do programa econômico do candidato da aliança PSB-Rede-PPS à Presidência da República" (OREIRO, 2014a). 
câmbio e indústria, como o intitulado "Acumulação de capital, taxa real de câmbio e catching-up" (2013). ${ }^{11}$

O novo desenvolvimentismo defende que, embora o desenvolvimento também dependa de fatores do lado da oferta, como boas instituições, educação, infraestrutura etc., o ponto de estrangulamento estaria no lado da demanda. Se o desenvolvimento necessita de uma alta taxa de investimento, então é necessário que seja correspondido por boa demanda, interna e externa. Porém Bresser-Pereira afirma que essas demandas tendem a ser insuficientes nos países em desenvolvimento devido a tendências estruturais: a) a demanda interna é deprimida pela tendência do salário crescer menos do que a produtividade, já que há oferta ilimitada de mão de obra barata, criando um problema de insuficiência do mercado interno ${ }^{12}$; b) já a demanda externa não é alcançada devido à tendência à sobrevalorização cíclica da taxa de câmbio, pois não existiria nem uma taxa de câmbio de equilíbrio intertemporal para a conta-corrente do país (teoria neoclássica), nem uma flutuação volátil em torno dela (keynesiana), já que nos países em desenvolvimento a taxa de câmbio não seria controlada pelo mercado, mas por crises no balanço de pagamentos. ${ }^{13}$

Para fazer frente ao problema da sobreapreciação cíclica da taxa de câmbio que impede o desenvolvimento, o novo desenvolvimentismo sugere a imposição de um imposto ou retenção sobre a exportação do bem primário que corresponda à diferença entre as taxas de câmbio de equilíbrio industrial e corrente, fazendo com que a moeda nacional deprecie-se, e também um crescimento baseado em poupança interna. A receita do imposto deveria então ser investida em um fundo soberano. O papel do Estado passa a ser de indutor de oportunidades de investimentos, ao mesmo tempo que cuida para zerar o déficit público (importante num cenário de doença holandesa) e aumentar a eficiência em gastos sociais e em cultura. Para a implantação dessa política seria necessário que a sociedade civil fosse consensual quanto aos objetivos do novo desenvolvimentismo, e isso significaria fazer frente, principalmente, à hegemônica ideologia neoliberal e à nacional dependência das elites nacionais.

Ainda em Bresser-Pereira (2012b), o autor se empenha em mostrar o distanciamento da ortodoxia convencional do novo desenvolvimentismo ao revelar a

11 Mais publicações dos autores novo desenvolvimentistas podem ser consultadas no site do grupo Macroeconomia Estruturalista do Desenvolvimento, e nas páginas pessoais on-line de Luiz Carlos Bresser-Pereira e de José Luis Oreiro.

12 Sobre esse aspecto, os novos desenvolvimentistas se apoiam na teórica clássica do desenvolvimento de Arthur Lewis.

13 A crise cíclica se dá, num primeiro momento, porque há suspensão da rolagem da dívida (perda de confiança dos credores externos) forçando a desvalorização da moeda local. A taxa de câmbio volta a se apreciar gradualmente puxada pela doença holandesa, por déficits em conta corrente causados pelo crescimento com poupança externa, política anti-inflacionária e por "populismo cambial". A crise externa volta a crescer até o ponto em que os credores internacionais não mais aceitam rolar a dívida e outra crise acontece. 
dupla necessidade do mercado forte, mas também de um Estado forte, sem que um seja inibidor do outro. Desse modo, o novo desenvolvimentismo seria pragmático, e não fundamentalista de mercado como a ideologia da ortodoxia convencional, que é baseada na teoria neoclássica.

Bresser-Pereira também discute as principais diferenças entre o antigo e o novo desenvolvimentismo (2012b). Elas estariam relacionadas às mudanças que ocorreram de lá para cá, quando muitos dos países latino-americanos deixaram de ser pobres, se industrializaram e tornaram-se países de renda média. Assim, a indústria agora não é mais infante e não necessita de proteção generalizada. Logo, o autor enfatiza a necessidade de um câmbio competitivo, passando do modelo de substituição de importações para o modelo exportador. Neste, o mercado disponível não se limita ao interno, e a política industrial passa a beneficiar somente as empresas eficientes, que tenham inserção externa. Para o autor, o Estado passa a ter muito mais um papel normativo, de facilitar e encorajar o investimento privado do que de propriamente ser protagonista na produção.

\subsection{O Programa (neo)liberal da Casa das Garças}

Da mesma forma que foi escolhido como simplificação o texto de Bielschowsky (2012) como paradigmático da corrente social-desenvolvimentista, nesta seção se prioriza o artigo de Edmar Bacha (2013), intitulado "Integrar para crescer: o Brasil na economia mundial". ${ }^{14}$ Bacha (2013) sugere que a economia brasileira tem baixa inserção no comércio internacional, trazendo como consequências, por exemplo, o atraso tecnológico, a escala de produção reduzida e a falta de especialização, que, por sua vez, tem relações com o baixo crescimento econômico, a elevada inflação e a desindustrialização. Para o autor, se no período 2004-2011 a conjuntura externa permitiu à nossa economia aproveitar os altos preços de commodities e o bom fluxo de capitais estrangeiros, a situação a partir de 2011 modificou-se e trouxe à tona a "doença brasileira": elevada inflação combinada com reduzido crescimento econômico. ${ }^{15}$

14 Todavia, inúmeros textos acadêmicos e midiáticos podem ser acessados no site do Instituto de Estudos de Política Econômica - Casa das Garças. Ver < http://iepecdg.com.br >.

15 Esse parece ser o projeto nacional ou linha de pensamento econômico utilizada pela chapa de Aécio Neves do Partido da Social Democracia Brasileira (PSDB) na eleição presidencial de 2014. Em entrevista para a Revista Época Negócios, de março de 2014, Bresser-Pereira (KUPFER, 2014) afirma categoricamente que o partido político PSDB e seu candidato à presidência possuem forte aproximação com o pensamento da Casa das Garças. Segundo Bresser-Pereira, "[...] no caso do Aécio a gente conhece muito bem, é a Casa das Garças, um grupo altamente ortodoxo, dominado pelas tendências do liberalismo econômico". Em entrevista ao Estado de São Paulo, no dia 15 de março de 2014, Edmar Bacha declarou sua posição partidária e se mostrou um consultor informal do programa de Aécio Neves. ESP: “O sr. já apresentou essa proposta [de abertura para o comércio internacional] a algum candidato?" EB: "Obviamente eu discuto essas ideias. Vocês devem querer saber sobre a minha relação com o Aécio. Não é segredo para ninguém que sou tucano. Mas não estou na campanha. Quando o Aécio me pergunta alguma coisa, eu apenas digo 
Alguns fatores internos que alimentariam a doença brasileira são o baixo investimento (18\% do PIB em 2012, segundo o IBGE), a alta carga tributária - que "[...] sufoca os investimentos privados e não promove o investimento público" (BACHA, 2013, p. 2) - e a educação precária - refletindo baixa qualificação da mão de obra, como observado nos exames Pisa da OCDE. Além disso, outro fator que tem tido menos espaço no debate, analisa Bacha (2013), é justamente o da baixa participação da economia brasileira no comércio mundial. A proposta do autor para a estratégia de desenvolvimento, do ponto de vista qualitativo, é que não se tente atacar todas as mazelas da economia de uma só vez, mas que se adote o princípio de desenvolvimento desequilibrado de Hirschman, um desequilíbrio regenerador. Nesse sentido, deveria haver maior "exportabilidade" da economia, de modo a se integrar às cadeias internacionais de valor (em 2012, pelo World FactBook, enquanto sétima maior economia do mundo, em termos de valores de exportação de mercadorias, o Brasil ficou no 250 lugar, o que contrasta bastante com as posições nos rankings de países ricos ou que conseguiram transitar para o primeiro mundo, como a Coreia do Sul: 130 PIB global e 7o maior exportador).

Bacha (2013) entende que a economia brasileira foi bem-sucedida ao construir uma indústria de transformação substancial a partir da substituição de importações, mas acredita que faltou um segundo passo, que é produzir não apenas para o mercado interno. Para ele, do lado das importações, a economia brasileira também seria pouco integrada, tendo como parcela de importações de bens e serviços no PIB 13\%, enquanto a Coreia do Sul tem 54\%, a Alemanha, 45\%, a Chi-

o que eu acho." (SALOMÃO; NEDER, 2014). Gustavo Franco (2014) externa sua opção pela política do PSDB em entrevista ao Estado de São Paulo. ESP: "No evento de 20 anos do plano real, o ex-presidente Fernando Henrique Cardoso disse que era preciso dar continuidade a um processo interrompido. A proposta é essa, então?” GF: “Claro. É preciso retomar. Isso não quer dizer que aquilo feito no intervalo pelo Partido dos Trabalhadores deva ser jogado fora. Nada disso. O Brasil andou. Lições foram aprendidas. Mas é preciso retomar políticas públicas com o intuito de fazer crescer a competitividade e o crescimento. A fórmula de buscar o crescimento empregada pelo governo não deu certo. Pelo menos quando deu foi por fatores cuja efetividade foi derrotada". ESP: “Como são as discussões no PSDB: há uma visão única ou ainda há divergências?" GF: "Não sei. O PSDB não é assim. Converso muito com gente do PSDB, mas ocorreram pouquíssimas conversas organizadas. Agora, os grupos maiores, que começaram a ser reunir, se dispersam e voltam a se reunir conforme o desejo do candidato. Há alguns economistas muito próximos ao Aécio - Armínio (Armínio Fraga, ex-presidente do Banco Central), Mansueto (Mansueto Almeida, Pesquisador do Instituto de Pesquisa Econômica Aplicada), José Roberto (José Roberto Mendonça de Barros, ex-secretário de Política Econômica), Samuel (professor e pesquisador Samuel Pessôa). Pode perguntar para ele". Outra reportagem, do Jornal O Povo (O POVO ONLINE, 2014), mostra o posicionamento de economistas em torno da campanha de Aécio: "O economista e pesquisador do Instituto Brasileiro de Economia (Ibre) da Fundação Getulio Vargas (FGV), Samuel Pessôa, confirmou em conversa com o Broadcast que já trabalha na formulação da agenda econômica do provável candidato à Presidência Aécio Neves (PSDB). 'Tenho conversado com o senador há quatro meses', afirmou. Segundo ele, ainda não há pontos do programa definidos, mas certamente o cenário do ano que vem será de 'um ajustamento duro da economia'. Durante evento ontem em São Paulo, Aécio afirmou que o ex-presidente do Banco Central (BC), Armínio Fraga, 'ao lado de figuras como José Roberto Mendonça de Barros, Mansueto (Almeida) e Samuel Pessôa, são economistas que estão nos ajudando com a construção de uma agenda para o Brasil.'” 
na, 27\%, etc. (dados de 2012 do Banco Mundial). Se comercialmente o país está relativamente fechado, financeiramente está aberto ao investimento estrangeiro direto, como mostra o quarto lugar no ranking de destinos preferenciais para essas inversões. Porém, as multinacionais que vêm para o Brasil teriam como objetivo explorar o mercado interno protegido, e não integrar o país nas cadeias produtivas globais (como ocorre quando as subsidiárias são abertas na Ásia). Ter a conta de capital aberta ao fluxo de investimento ao mesmo tempo que mantém a conta corrente fechada ao fluxo comercial representa, para o autor, um paradoxo perigoso, pois as empresas “[...] multinacionais lucram ao investir no país, mas o resto da economia definha, ao deslocar para a substituição protegida de importações recursos locais que poderiam ser empregados com maior eficiência em atividades exportadoras" (BACHA, 2013, p. 4). Nesse sentido, a proposta defende maior abertura comercial para garantia de eficiência nacional.

Para que o programa de integração seja bem-sucedido e sustentável, defende Bacha (2013), é preciso haver consenso político e social, que “[...] poderia ser obtido a partir da evidência que o protecionismo claramente não vem conseguindo desenvolver o país" (BACHA, 2013, p. 12) e, para que isso ocorra, duas constatações precisariam ser assimiladas. A primeira é que o isolamento econômico de nossa economia não conseguirá retirar o país da tendência de pequenos PIBs e de renda média. ${ }^{16} \mathrm{O}$ autor lista os exemplos dos países que alcançaram o desenvolvimento no pós-guerra e afirma que cada um deles, à sua maneira, seja por exportações industriais, de serviços ou de commodities, aumentou sua integração com o comércio mundial. A segunda é que os acordos de preferência comercial (APCs) são hoje uma característica irreversível da regulação do comércio internacional e sua intensificação mostra que os países reconhecem que no atual mundo globalizado é preciso interdependência para acelerar o crescimento. Bacha (2013) defende essa associação entre comércio e riqueza, pois considera que a transformação de um país de renda média em um país de renda alta é mais complicada que o passo anterior de sair da situação de renda baixa, já que os ganhos adicionais de produtividade que geram esse aumento dependem de fatores que somente podem ser obtidos através da integração do país ao comércio internacional, como empresas com escala, especialização e tecnologia. ${ }^{17}$

16 É feita referência ao modelo social-desenvolvimentista sobre o grande potencial de crescimento a partir do mercado interno, acompanhada da crítica de que essas oportunidades podem ser desperdiçadas "[...] se prevalecer uma mentalidade anticompetitiva, de preservação do mercado interno contra uma suposta invasão dos importados, de desenhos inadequados das concessões e parcerias público-privadas, e de encarecimento da exploração do pré-sal com requisitos excessivos de intervenção estatal e de conteúdo nacional" (BACHA, 2013, p. 7).

17 Para se obter a renda média, as condições seriam mais amenas, sem necessidade de muito comércio, mas poder-se-ia utilizar-se do mercado interno, da substituição de importações e da oferta ilimitada de mão de obra do campo para elevar a renda, "conforme diagnosticado na análise clássica de Arthur Lewis" (BACHA, 2013, p. 5). 
Bacha (2013) destaca que a ideia da estratégia não é transformar o país em uma plataforma exportadora, dado seu tamanho muito grande, mas integrar competitivamente "[...] as empresas aqui localizadas às cadeias mundiais de valor" (BACHA, 2013, p. 6), sem que isso signifique contenção da demanda interna ou maior superávit comercial, pois o aumento das exportações deverá ser igualado por um aumento das importações no mesmo montante. A proposta, então, segundo o autor, seria condizente com melhorias nas condições de vida da população, mesmo no curto prazo, pois haveria maior demanda por trabalho e aumento do salário real. As multinacionais presentes no Brasil deveriam então partir da posição privilegiada no mercado interno para desenvolverem atividades exportadoras. $\mathrm{O}$ exemplo a se guiar seria o da Embraer, que importa $70 \%$ do que exporta. ${ }^{18}$

Assim, o programa sugerido tem três pilares: a reforma fiscal, a substituição de tarifas por câmbio e os acordos comerciais. ${ }^{19} \mathrm{~A}$ reforma fiscal requer a simplificação e a redução da carga tributária sobre as empresas sem incorrer em aumento da dívida pública, controlando os gastos públicos. Serviria de exemplo a fórmula

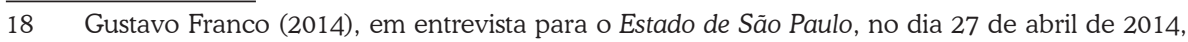
explicita a crítica ao modelo atual e defende a volta da liberalização econômica dos anos 1990: "Mas, bom, sobre indústria - é preciso mudar os termos do problema. Depois do Real, estávamos caminhando para uma progressiva integração da indústria para a economia global. Uma economia com muitas empresas multinacionais, com toda a capacidade para fazer com que o Brasil se integrasse às cadeias globais. Porém, uma das marcas do governo PT foi reverter esse movimento, aumentar a proteção e voltar a uma lógica de industrialização dos anos 50 - forçar o aumento do componente local na produção industrial. Isso foi um equívoco que destruiu a nossa produtividade, seja para exportar, seja para competir com o importado. Talvez tenha sido uma das causas mais próximas do declínio industrial que a gente vem sofrendo nos últimos tempos. Poderíamos ter caminhado na direção totalmente oposta - fazer a indústria importar mais. Só exporta mais quem importa e só é competitivo quem é capaz de utilizar os melhores insumos existentes no mundo. Se a gente não tem acesso a esses componentes o que vai ocorrer é a reprodução da reserva de mercado - você se mete a produzir mercadorias na fronteira tecnológica com insumos inferiores, acaba tendo artigos não competitivos, com uma produtividade inferior. Onde a gente deu certo, o exemplo clássico, Embraer, é onde a gente exporta sem restrição de conteúdo local."

19 Sobre a preocupação com a inflação, Bacha (NOGUEIRA, 2013), em entrevista para a revista Isto é Dinheiro, do dia 27 de dezembro de 2013, indica que o governo tem de fazer política monetária contracionista e corte de gastos. RID: "Qual seria a meta ideal [de inflação]?” EB: "O Brasil precisa perseguir uma inflação de 3\%. Daí as pessoas falariam: 'Tudo bem, com essa inflação nós convivemos bem'”. RID: “Que medidas devem ser tomadas para isso?”. EB: “Uma ideia é manter a meta inflacionária de curto prazo, de 4,5\%, mas acrescentar outra de longo prazo, de 3\%, para 2020, por exemplo. Com isso, poderíamos pensar em coisas para assegurar que a inflação fique em $3 \%$, em 2020, indo além do controle de juros. É dar um reforço do Tesouro ao Banco Central, ou seja, aliar uma política de controle monetário a uma política de controle de expansão de gastos do governo. A outra proposta é como dar mais potência à política monetária. A principal é a constatação de que, do total do crédito, $50 \%$ não são afetados pela Selic. É o crédito que o BB dá para a agricultura, que a Caixa dá para a habitação e que o BNDES dá para os amigos do rei. Em nada disso o BC apita. Em Brasília, os presidentes dessas instituições dão tchauzinho para o pessoal do BC. A política monetária atua apenas sobre o crédito livre, o que gera um esforço duas vezes maior. A minha proposta é encontrar alguma maneira de incluir o crédito dos bancos públicos no âmbito da política monetária, de tal maneira que, quando o $\mathrm{BC}$ apita que vai subir os juros, o BNDES contraia os créditos dele". 
israelense de limitar o crescimento dos gastos públicos à metade do crescimento potencial do PIB, o que seria 1,5\% ao ano para 2013.

A substituição de tarifas por câmbio significa diminuir o protecionismo tarifário e desvalorizar o câmbio a um nível que fortaleça as empresas domésticas no exterior. Quanto aos acordos comerciais, o Brasil poderia usar do amplo mercado interno que tem para fazer acordos vantajosos, dada sua abertura às exportações de seus parceiros comerciais. Diante das várias possibilidades de acordos, o país teria que obter maior liberdade diante das regras de lista comum para negociação com terceiros países em voga no Mercosul. Nesse sentido, a perspectiva da Casa das Garças percebe o Mercosul como um empecilho à maior integração do Brasil ao comércio internacional.

\section{Desenvolvimentismo no Século XXl?}

Há no texto de Pedro Fonseca (2014) uma busca pela definição do conceito de desenvolvimentismo, de modo a deixar mais claro o debate brasileiro sobre o tema. Segundo o autor, o "[...] termo é geralmente utilizado para designar um fenômeno relativamente delimitado no tempo - século XX -, embora espacialmente mais diversificado" (FONSECA, 2014, p. 31). A formalização do conceito tem origem na observação de seus usos pela comunidade que trabalha com o termo. A metodologia empregada por Fonseca (2014) foi a de buscar um núcleo comum dos diversos atributos que o termo ganhou e verificar se existem características mínimas principais. Num passo seguinte, aplicou-se um teste em experiências históricas reconhecidamente rotuladas como desenvolvimentistas. ${ }^{20}$

Da consulta à literatura dessa época até a atualidade, Fonseca obteve um core do conceito alicerçado no tripé projeto nacional, intervenção consciente estatal e industrialização, tudo isso supondo uma conjuntura capitalista. O desenvolvimentismo remete a uma percepção de programa de ação e, assim, ganha sua primeira aproximação conceitual: "[...] é uma resposta para superar o subdesenvolvimento" (FONSECA, 2014, p. 44), nos termos de Celso Furtado.

20 No passo de observar experiências históricas tipificadas como exemplos de desenvolvimentismo, foram tomados 34 governos de 8 países latino-americanos entre 1930 e 1979. Testou-se a presença de 10 variáveis em cada caso, quais sejam: projeto nacional, intervenção estatal, industrialização, socialismo, capital estrangeiro, burocracia, reforma agrária, redistribuição de renda, planejamento e banco de desenvolvimento. Pode-se observar que as quatro primeiras variáveis representam o núcleo já discutido e, portanto, têm respostas idênticas para todos os casos analisados, ou seja, presença das três primeiras e ausência de intenção socialista. 
Nesses termos, Fonseca (2014, p. 59) encontra o seguinte conceito:

Entende-se por desenvolvimentismo a política econômica formulada e/ ou executada, de forma deliberada, por governos (nacionais ou subnacionais) para, através do crescimento da produção e da produtividade, sob a liderança do setor industrial, transformar a sociedade com vistas a alcançar fins desejáveis, destacadamente a superação de seus problemas econômicos e sociais, dentro dos marcos institucionais do sistema capitalista.

Utiliza-se esse conceito para verificar se as estratégias descritas na seção anterior vão ao seu encontro. Espera-se, assim, contribuir com uma dose a mais de rigor conceitual para a discussão contemporânea. Pela ausência da sugestão em qualquer das estratégias de alterar o modo de produção vigente, este artigo se concentra nas três bases do núcleo do conceito.

\subsection{Sobre Projeto Nacional}

As estratégias do social-desenvolvimento, do novo desenvolvimento e da Casa das Garças por si só podem ser caracterizadas como projetos nacionais, deliberados, "[...] tendo como objeto a nação e seu futuro" (FONSECA, 2014, p. 41). Todas colimam estabelecer diretrizes a serem seguidas de modo a levar o Brasil a uma posição melhor no futuro. Ficou claro na seção anterior que os meios sugeridos por elas para alcançar tal posição são bem diferentes entre si e é bem possível que os fins buscados também sejam.

Bielschowsky (2012) espera que a expansão das três correntes de demanda se traduza em um forte investimento e em um desenvolvimento brasileiro vigoroso para as próximas décadas. Bresser-Pereira e Gala (2010) defendem que sua ideia de desenvolvimento econômico é um processo de mudança estrutural, ou seja, "[...] de inovação nos setores já explorados e de transferência de mão de obra para setores com valor adicionado per capita e salários médios cada vez mais elevados" (BRESSER-PEREIRA; GALA, 2010, p. 666). A estratégia de Bacha (2013) parece objetivar um crescimento econômico que retire o país de uma condição de país de renda média para um país de renda alta. Percebe-se que não há consenso sobre o real significado do desenvolvimento que pretendem. Tal desenvolvimento poderia ser tanto uma sociedade mais igualitária alimentada por um crescimento econômico sustentável, quanto uma economia eficiente e forte que respeite contratos acima de tudo e que eleve a média dos salários do país. 


\subsection{Sobre Intervenção Estatal}

A intervenção estatal consciente com o objetivo de colocar o projeto em prática também se faz notar nas três estratégias. Varia bastante entre elas o modo como o Estado deve se comportar. Se no social-desenvolvimentismo o Estado é um agente indutor do investimento - que busca inclusive influenciar a demanda através de repasses às populosas camadas com rendas mais baixas com grande potencial de consumo -, no novo desenvolvimentismo a participação do capital privado já teria papel mais importante de imediato na questão da elevação do investimento - ao Estado caberia principalmente a manutenção de políticas que combatam as tendências estruturais dos salários crescerem menos do que a produtividade e do câmbio se sobreapreciar ciclicamente. Nesse sentido, o novo desenvolvimentismo propõe intervir nos principais preços macroeconômicos (câmbio, juros e salários), e não em aspectos mais estruturais, como infraestrutura, política industrial e política social, como defendem os sociais-desenvolvimentistas.

As questões relacionadas aos ajustes na taxa de câmbio e nas contas públicas, essenciais para a instituição da estratégia novo desenvolvimentista, são polêmicas. Em primeiro lugar, a ênfase nas exportações como motor do crescimento somente seria obtida com o alcance da taxa de câmbio de equilíbrio industrial, constituindo-se no curto prazo elevação da taxa de inflação e redução dos salários reais; ou seja, uma redistribuição de renda a favor dos lucros industriais em detrimento dos salários, num típico processo de socialização dos prejuízos, como prefere caracterizar Bastos (2012, p. 791).

Outra controvérsia nesse aspecto refere-se ao patamar da taxa de câmbio de equilíbrio industrial. Oreiro, Basílio e Souza (2013) chegam a defender uma megadesvalorização, com o câmbio no valor de $\mathrm{R} \$ 3,26$. Todavia, a cientificidade da taxa de câmbio de equilíbrio industrial encontrada pelos autores é contestável. Na verdade, os autores realizam um cálculo bastante simples, uma regra de três: em primeiro lugar, assumem que a relação câmbio real efetivo versus salários, "adequada" para restabelecer a competitividade da indústria, é a de meados de 2005. Assim, ao encontrarem o valor dessa variável, em junho de 2013, e a taxa de câmbio efetiva nesse mês, concluem pela sobrevalorização cambial de 48,12\%. Multiplicando esse valor pelo câmbio da época $(R \$ 2,20)$, chegam à taxa de $R \$$ 3,26. Nessa metodologia, logicamente a taxa de câmbio de equilíbrio industrial pode assumir qualquer magnitude dependendo do período que se considera apropriada a relação câmbio real efetivo versus salários. ${ }^{21}$

21 Além do mais, em um artigo do jornal Valor Econômico, do dia 19 de fevereiro de 2013, Bresser-Pereira (2013) defende uma taxa de câmbio de equilíbrio industrial de $\mathrm{R} \$ 2,80$. Todavia, em entrevista do dia 17 de dezembro de 2012, (BRESSER-PEREIRA, 2012d) a taxa de equilibro defendida era ainda de R\$ 2,70. Nesse sentido, entre os próprios novos desenvolvimentistas não há um consenso sobre o valor da taxa de câmbio de equilỉbrio industrial, apesar de que teoricamente a argumentação seja relevante. 
Em segundo lugar, tem-se a problemática do ajuste nas contas públicas defendida pela corrente novo desenvolvimentista. Seus defensores argumentam que a taxa de juros no Brasil é muito elevada pelos recorrentes déficits em conta-corrente do governo. Nesse sentido, a redução dos juros somente poderia ser realizada se ex ante o governo se tornasse superavitário. Segundo Bastos (2012), esse ajuste nas contas públicas poderia implicar uma redução no gasto público de até $8 \%$ do PIB. Logicamente, trata-se de um programa de ajuste recessivo.

Percebe-se que a estratégia novo desenvolvimentista prioriza, sobretudo, a administração de preços macroeconômicos - câmbio, juros e salários - para a garantia do crescimento sustentado (BASTOS, 2012). A taxa de câmbio ideal seria a de equilíbrio industrial, que permitiria que as empresas nacionais competissem no mercado internacional, além da administrar a doença holandesa. A taxa de juros em patamares reduzidos seria fundamental para impedir a valorização artificial da taxa de câmbio e o déficit público. Os salários deveriam crescer a uma taxa de acordo com a produtividade do trabalho, nem aquém, tampouco acima. ${ }^{22}$ Neste caso, os novos desenvolvimentistas criticam abertamente a política nacional em vigor de valorização do salário mínimo acima da produtividade, ou a defesa de um modelo de crescimento wage-led, defendido pelos sociais-desenvolvimentistas. Segundo Oreiro (2012, p. 29, grifo do autor), a:

[...] manutenção da taxa real de câmbio num patamar competitivo nos médio e longo prazos exige não só a adoção de uma política cambial ativa, como também uma política salarial que promova a moderação salarial ao vincular o aumento dos salários reais ao crescimento da produtividade do trabalho, garantindo assim a estabilidade da distribuição funcional da renda no longo prazo.

O argumento é que um aumento cumulativo da participação dos salários na renda nacional - condição necessária para a ocorrência de um crescimento autônomo dos gastos de consumo - é econômica e até politicamente inviável por produzir tendência de queda da taxa de lucro ${ }^{23}$ via estagnação da acumulação de

22 Escreve Oreiro (2013a): "O crescimento dos salários na frente da produtividade do trabalho não só leva a perda de competitividade da indústria como ainda contribui para manter a inflação em patamares elevados devido a pressão de custos. O resultado da apreciação cambial e do aumento do custo unitário do trabalho é, portanto, estagnação da produção industrial combinada com inflação em patamares elevados, a velha 'estagflação'".

23 É o que busca deixar claro Eleutério Prado (2014) em texto publicado em seu . Para ele, Oreiro, "[...] este autor heterodoxo vem apontar como causa da estagnação recente do capitalismo no Brasil a redução da taxa de exploração e, assim, a redução consequente da taxa de lucro". Em discussão que se segue, Prado (2014) afirma que Oreiro busca "[...] tirar no curto prazo salário real dos trabalhadores para lhes dar mais crescimento e, assim, mais salário real no futuro. Eles, no entanto, precisam saber bem o que essa proposta significa. Oreiro (2014b) se defende escrevendo que ele não busca "[...] tirar salário real dos trabalhadores, a redução do salário real virá de qualquer jeito, pois o atual nível de salários - e de câmbio real - é insustentável. Das duas uma, ou o salário real será reduzido por intermédio de uma desvalorização abrupta da taxa de 
capital e reação da classe capitalista ao seu possível processo de perda de participação na renda.

A questão da intervenção estatal na corrente da Casa das Garças remete a princípios relativos ao approach neoclássico e, na maioria das vezes, é condenável. Bacha (2013) propõe que o Estado seja um agente confiável, que antecipe suas decisões para o mercado poder agir com tranquilidade, e que consiga estabelecer um consenso social e político em torno do projeto de integração. Para isso, teria que afastar um pouco de sua influência na economia, com uma reforma fiscal, com menos protecionismo, permitindo um câmbio mais favorável para as empresas em solo nacional se tornarem exportadoras. A política industrial também é colocada em segundo plano. Na verdade, é condenada por priorizar determinados setores em detrimento de outros, o que aproxima nesse aspecto o pensamento da Casa das Garças ao novo desenvolvimentismo. O que certamente diferencia essas duas correntes é que os novos desenvolvimentistas defendem a administração da taxa de juros e salários. Na perspectiva da Casa das Garças, tais preços macroeconômicos seriam determinados pelas forças do mercado.

Ainda, no programa da Casa das Garças, a "doença brasileira" se caracteriza por uma economia que sofre do mal de ter crescimento baixo e inflação alta. Atesta-se desde já que essa afirmativa é altamente contestável, já que a taxa de inflação brasileira não extrapolou na última década as metas predefinidas pelo Copom, e a taxa média de crescimento do PIB é superior à dos anos 1990.

O ponto sobre a substituição de proteção tarifária do mercado interno por proteção cambial trata de anunciar uma série de medidas - a redução de tarifas para as importações, dos requisitos de conteúdo nacional, das preferências para compras governamentais, das amarras aduaneiras e portuárias etc. - com o intuito de sinalizar uma alteração para o mercado. O anúncio dessas medidas faria os agentes financeiros procurarem dólares na expectativa de lucrar com as importações que ocorreriam em decorrência da queda de barreiras tarifárias. A maior demanda por dólares, então, desvalorizaria o câmbio.

Nesse sentido, a desvalorização cambial serviria como uma espécie de protecionismo horizontal, semelhante à proposta novo desenvolvimentista. $\mathrm{O}$ antiprotecionismo tarifário permitiria acesso a insumos modernos e possibilitaria a integração da indústria brasileira ao comércio internacional, gerando ganhos de tecnologia, de escala e de especialização. Bacha (2013) ressalta, ainda, que a es-

câmbio em função de uma crise de balanço de pagamentos ou poderá vir por intermédio de uma combinação entre moderação salarial e desvalorização administrada e, portanto, suave da taxa de câmbio. Eu, claramente, prefiro a segunda opção; mas francamente acho que ocorrerá a primeira". Em artigo do dia 24 de outubro de 2013, da revista Valor, Oreiro (2013b) argumenta mais sobre a redução dos salários reais: "Não é algo a ser feito da noite para o dia [...]. Estamos vivendo um momento de realinhamento das taxas cambiais no mundo, invariavelmente isso vai afetar os salários. A redução do ganho real de salários, em torno de $20 \%$, deve ser algo para ser feito em cinco, seis anos". 
pecialização não é macrossetorial e que o princípio das vantagens comparativas se daria não em termos de produtos ou indústrias, mas quanto a estágios, tarefas e atividades. O sequenciamento da liberalização comercial teria de ser mais bem estudado, no sentido de uniformizar a tarifa efetiva para todos os produtos, insumos ou produtos finais, com a possível exceção de indústrias nascentes. Fica claro que a proposta é a de uma nova rodada de abertura, no sentido de continuidade às reformas neoliberais praticadas ao longo da década de 1990.

A corrente da Casa das Garças, ao preconizar uma reforma fiscal via corte de despesas, explicitamente admite um intervencionismo estatal menor do que o atual. Em geral, recomenda cortes de despesas de custeio, o que levaria certamente a menores gastos com saúde, educação, políticas sociais, inovação, etc. Ou seja, a proposta indiretamente sugere cortes em políticas sociais redistributivas, distanciando-se das priorizadas pelos últimos governos e aproximando-se novamente da praticada ao longo da década de 1990. Nesse sentido, o pilar intervencionista na corrente da Casa das Garças é minimizado. O Estado a priori é tratado como ineficiente e a maneira de reduzir sua ineficiência é reduzir gastos. Diante dessas evidências, essa corrente não é caracterizada como intervencionista de Estado, pois se distancia do core do conceito de Fonseca (2014).

Cabe destacar que alguns autores comprovam os avanços intervencionistas obtidos pelo governo Lula, em especial os relacionados à bandeira da luta contra a pobreza. Singer (2010) afirma que as melhoras efetivas para a parcela da população pobre brasileira representam um realinhamento eleitoral em torno dessa agenda, e que não mais poderá ser abandonada "sob o risco de morte política". Para ele, o "lulismo" tende a erradicar a pobreza monetária absoluta num intervalo pequeno de tempo, mas não uma sociedade desigual no mesmo período, pois a tendência de redução da desigualdade se faz lentamente. Erber (2011) também compartilha da ideia de que a prioridade do combate à pobreza não deve mais sair da agenda desenvolvimentista. Para o autor, no governo Lula a convenção mais ligada a essa agenda, a convenção neodesenvolvimentista, que também se baseia em maior atuação do Estado, principalmente em infraestrutura e construção residencial, existiu, mas foi subordinada à outra, à convenção institucionalista restrita, centrada na teorização neoclássica e defendida pelo Ministério da Fazenda e pelo Banco Central.

\subsection{Sobre Industrialização}

A terceira característica presente no núcleo comum principal, a industrialização - "[...] como caminho para acelerar o crescimento econômico, a produtividade e a difusão do progresso técnico [...]" de modo que haja aumento da produção e da produtividade, fazendo desse o ponto central da estratégia econômica e se 
afastando da ortodoxia, que prima pela estabilidade (FONSECA, 2014, p. 41) apesar de também estar presente nos três modelos, merece mais cuidado. Em Bielschowsky (2012), é a demanda interna que será trabalhada e deverá ser seguida pelo investimento, principalmente em bens de consumo e em infraestrutura, sendo, então, aproveitada pelos encadeamentos produtivos. Ao mesmo tempo que se preocupa com a reprimarização, espera o fortalecimento das atividades primárias e dos serviços. Todavia, para essa corrente a indústria segue sendo o setor mais estratégico.

Para Bresser-Pereira (2010), a política econômica tem de buscar fortalecer a indústria ao tratar dos gargalos, interno e externo, da demanda. No mesmo sentido, José Luis Oreiro possui inúmeros artigos acadêmicos procurando defender a indústria como um setor-chave do crescimento. Nesses termos, são críticos ao processo de desindustrialização brasileiro em marcha nas últimas décadas.

Já para Bacha (2013), é clara a proposta de maior integração da indústria brasileira ao comércio mundial, esteja sob comando nacional ou não. Entretanto, o foco parece estar muito mais em criar uma atmosfera propícia para o desenvolvimento de atividades lucrativas - exportação de commodities, de serviços ou de manufaturados - nas quais o governo deve conter sua ação à reforma fiscal, à manutenção de um câmbio favorável para a exportação e evitar o protecionismo. Portanto, não há prioridade na atividade ou setor a ser desenvolvido - devido à diversificação e escala da economia brasileira, Bacha defende a integração por esses três setores. ${ }^{24}$

No livro organizado por Edmar Bacha e Mônica Baumgarten de Bolle (2013), intitulado O futuro da indústria no Brasil: desindustrialização em debate, transparece a ideia de que existe o fenômeno da desindustrialização no Brasil, mas que não é problemático. Na verdade, os autores chegam a perceber o fenômeno como salutar, como um processo de ajuste, já que a economia brasileira até a década de 1980 encontrava-se sobreindustrializada para os padrões normais da época. Bonelli, Pessôa e Matos (2013) chegam à conclusão de que “[...] os exercícios econométricos confirmam a existência de uma indústria com peso muito acima do normal de meados dos anos 1970 até a segunda metade dos anos 1980. A partir daí, ela converge para o padrão normal" (BONELLI; PESSÔA; MATOS, 2013, p. 71). A sobreindustrialização ocorrida até a década de 1980 é denominada de "doença soviética”. Nesse sentido, na contramão de toda a literatura que critica o

24 Na verdade, os principais expoentes da Casa das Garças abertamente não consideram a indústria um setor especial para a instituição de uma estratégia de desenvolvimento. Em um artigo recente para o jornal Folha de São Paulo, intitulado "Indústria e câmbio, a missão", do dia 23 de março de 2014, Samuel Pessôa afirma categoricamente sua posição a respeito da indústria de transformação: "Não há evidência de que a indústria de transformação seja especial sob algum critério. Isto é, não há evidência de que o retorno social da atividade industrial seja maior do que o da agricultura o da pecuária, o da indústria extrativa mineral ou o das diversas atividades do setor de serviços". 
ajuste neoliberal ocorrido nos anos 1990, os autores entendem essa década como benéfica, já que o abrupto processo de abertura comercial e financeira teria curado o Brasil de sua doença soviética. Assim, a desindustrialização é benéfica, já que possibilitou ao país a convergência para a média internacional de participação da indústria no PIB.

Considera-se relevante que os defensores do benéfico processo de ajustamento brasileiro em direção à média mundial de participação manufatureira no PIB respondam duas questões relevantes: a) por que quando o Brasil converge para a média mundial de participação da manufatura no PIB, próxima à média das economias desenvolvidas, também não converge sua renda per capita ao nível desses países?; b) por que os países que estiveram sobreindustrializados (ou sofrendo com a maldição da doença soviética) nas últimas décadas apresentaram taxas de crescimento da renda per capita e do PIB substancialmente mais elevadas que as dos países que se ajustaram? O fato estilizado das trajetórias nacionais de desenvolvimento, conforme atesta Rodrik (2006), sugere que a melhor estratégia para se alcançar níveis elevados de renda per capita para um país em desenvolvimento é encontrar-se sobreindustrializado.

No programa da Casa das Garças, depara-se com uma estratégia para o país que não enfatiza suficientemente a indústria como carro chefe da economia, apesar de não descartá-la. Se esse é o caso, de acordo com a definição de desenvolvimentismo adotado neste artigo, apenas as estratégias do social-desenvolvimentismo e do novo desenvolvimentismo podem ser caracterizadas como estratégias desenvolvimentistas para o Brasil. ${ }^{25} \mathrm{O}$ Quadro 2 explicita esse entendimento.

Quadro 2 - Presença das características definidoras do desenvolvimentismo

\begin{tabular}{|l|c|c|c|}
\hline & Projeto nacional & $\begin{array}{c}\text { Intervenção } \\
\text { consciente } \\
\text { estatal }\end{array}$ & Industrialização \\
\hline $\begin{array}{l}\text { Social-desen- } \\
\text { volvimentismo }\end{array}$ & $\operatorname{Sim}$ & $\operatorname{Sim}$ & $\operatorname{Sim}$ \\
\hline $\begin{array}{l}\text { Novo desen- } \\
\text { volvimentismo }\end{array}$ & $\mathrm{Sim}$ & $\mathrm{Sim}$ & $\mathrm{Sim}$ \\
\hline CdG/FGV & $\mathrm{Sim}$ & $\mathrm{Não}$ & Não \\
\hline
\end{tabular}

Fonte: Elaboração própria.

25 O resultado quanto à estratégia novo desenvolvimentista vai ao encontro do que Mollo e Fonseca (2013) realizaram ao compará-la ao nacional desenvolvimentismo utilizando essas três características que formam seu núcleo duro. 
Pode-se classificar as estratégias estudadas de acordo com o conceito de desenvolvimentismo. Para isso, seria interessante destacar alguns de seus pontos fundamentais para colaborar no avanço da discussão. A próxima seção procura realizar essa tarefa.

\section{Ampliando os Elementos Constituintes do Desenvolvimentismo para o Sé- culo XXI}

Esta seção procura mostrar que as duas estratégias desenvolvimentistas em debate têm prós e contras e que, para o benefício do objetivo maior do desenvolvimento nacional, alguns de seus pontos deveriam ser mesclados, obtendo-se uma evolução na abordagem. Em primeiro lugar, se reconhece que o Brasil deve se valer do potencial de seu dinamismo do mercado interno, proporcionado pelos ganhos decorrentes de uma melhor distribuição de renda, como apregoa o social-desenvolvimentismo, mas não unicamente. A estratégia de aproveitar a demanda externa inserindo-se competitivamente no mercado global é vital, como defende o novo desenvolvimentismo, todavia sem que isso signifique dar incentivos ao capital em detrimento do proletariado do país, ou mesmo implementar medidas de cunho austero que malogrem os ganhos reais dos trabalhadores.

O problema estrutural relevante da economia brasileira contemporânea está diretamente atrelado a sua relativa estagnação da produtividade. Segundo Cavalcante e Negri (2014), os fatores que concorreram para o ciclo de crescimento econômico e a inclusão social a partir dos anos 2000 envolviam as políticas sociais de redistribuição de renda e de valorização do salário mínimo, a expansão do crédito, a incorporação de um grande contingente de população ao mercado de trabalho e de consumo e um cenário externo de crescimento acelerado que impulsionou a valorização de commodities exportadas pelo Brasil. O ciclo esteve, portanto, fortemente associado ao crescimento da taxa de ocupação e de participação e não parece ter sido acompanhado, na mesma proporção, pelo crescimento dos indicadores de produtividade. Todavia, num futuro próximo, a preservação de maiores taxas de crescimento do PIB per capita somente pode ser alcançada se houver um crescimento representativo da produtividade do trabalho ao longo dos próximos anos, uma vez que não se espera uma elevação das taxas de participação e ocupação. Essa debilidade do capitalismo brasileiro vem restringindo sua capacidade de aproveitar impulsos de demanda interna e externa, já que se trata de um problema estrutural, e não conjuntural.

Talvez diante das dificuldades impostas pelo perfil não inovante das empresas nacionais, Bielschowsky (2012), com o objetivo de tornar sua estratégia o mais viável e o mais próximo da realidade possível, inserida numa mera possibilidade histórica, relega a um segundo plano a importância das inovações para o desenvolvi- 
mento. Seja como for, se a ideia de formular uma estratégia é justamente externar possibilidades a ser aproveitadas para transformar uma realidade, entende-se que a inovação deva ser protagonista nas políticas implementadas, tanto visando o mercado interno, quanto a melhor inserção no comércio internacional. Não sendo o esforço científico e tecnológico ainda maduro no país, e logo não podendo se estabelecer como motor do desenvolvimento no curto prazo, o autor espera que essa situação se altere no futuro e que o país descubra nichos de progresso técnico para concentrar-se. Concorda-se em parte com essa visão, mas parece urgir o esforço em certos nichos já neste momento, enquanto a janela de oportunidade para inserção no possível novo paradigma ainda está aberta (PÉREZ, 2010). Entretanto, isso faz da inovação o tópico principal de uma estratégia bem-sucedida para o século XXI.

Algumas ressalvas importantes que Bielschowsky (2012) considera valem destaque. Ele escreve que está "[...] propositadamente ausente, na formulação, a ideia frequente de que exportações de bens industriais possam ser um motor de investimento em si mesmos" (BIELSCHOWSKY, 2012, p. 730), uma vez que foi constatado que as empresas que produzem no Brasil estão essencialmente preocupadas com o mercado interno e que o mercado externo representa apenas um complemento. Diante desse fato, as empresas deveriam ganhar corpo se utilizando da demanda interna brasileira para somente então buscar terreno no exterior (growth-led export). Isso seria um passo no futuro, após ampla utilização da demanda nacional. Apesar de essa ser, no caso dessa estratégia, ${ }^{26}$ uma preocupação apenas para o longo prazo, já provoca inquietação o modo como se daria a inserção internacional das empresas nacionais. Ganhar escala e produtividade parece pouco para fazer diante da concorrência forte no mercado externo, ou ainda, para frear os efeitos da dependência tecnológica e da restrição externa ao crescimento.

Para produzir os bens mais rentáveis que são demandados pelo mercado globalizado é preciso estar no estado da arte da tecnologia, o que se mostra complicado quando as empresas se voltam para a demanda brasileira, que, por sua vez, apresenta certas características de um país culturalmente e tecnologicamente dependente, à la Celso Furtado. Se a demanda interna é culturalmente dependente, ela é imitativa dos padrões de consumo da demanda global. Se os brasileiros estão preocupados em demandar o que há de mais moderno no mercado, as empresas que aqui atuam e para eles produzem precisam se reinventar todo o tempo, adaptando seu parque produtivo, comprando novidades em bens de capital e insumos para tentar seguir o rastro das empresas inovadoras - logo, são tecnologicamente

26 “[...] inovação não é aqui considerada como uma frente de expansão em si mesma, já que a atividade de PẺD no país ainda não está suficientemente inserida nas estratégias de expansão das empresas. Se isso vier a ocorrer, como se dá nos países mais desenvolvidos, a inovação poderá tornar-se um quarto motor do desenvolvimento a longo prazo" (BIELSCHOWSKY, 2012, p. 731). 
dependentes. O resultado é problemático já a curto prazo, basta observar os déficits recorrentes em transações correntes do país. Talvez, por limitar-se à dimensão econômica, o autor não considere tal abordagem e tal entrave. Nesse sentido, a questão da restrição externa ao crescimento deveria estar presente na agenda.

Quanto ao novo desenvolvimentismo, seus defensores, segundo Mollo e Fonseca (2013, p. 223), enfatizam diferenças entre este e o desenvolvimentismo do século XX, que "[...] não são evidentes por si mesmas, e devem ser questionadas" para que não se criem distorções. Como já citado, o novo desenvolvimentismo compartilha do mesmo núcleo duro do antigo, mas, para Mollo e Fonseca (2013, p. 223), seus defensores "[...] mostram certa incompreensão na maneira de conceber o desenvolvimentismo antigo". Primeiramente, argumentariam a necessidade de uma nova estratégia, já que a antiga está associada à irresponsabilidade fiscal ou despreocupação inflacionária, o que a ortodoxia viria a criticar como populismo econômico. ${ }^{27} \mathrm{O}$ novo, então, teria de ser pensado como uma terceira via, o que Mollo e Fonseca (2013) dizem fazer com que essa estratégia pareça concordar com a crítica. Os autores usam, então, o contraexemplo dos governos de Vargas para mostrar que essas críticas, essa associação entre desenvolvimentismo e irresponsabilidade, não procedem.

Além disso, Mollo e Fonseca (2013) alertam para o fato de que a ênfase da estratégia novo desenvolvimentista se faz na taxa de câmbio, pois o tipo de industrialização sugerida e que faz a economia crescer é aquela voltada para as exportações (export-led) e que contrasta com o modelo de crescimento via mercado interno com substituição de importações (wage-led). A prioridade, então, parece se dar mais no crescimento econômico do que na elevação dos salários e do PIB per capita. Mollo e Fonseca (2013) sugerem que se a prioridade não fosse exportar, a variável-chave não seria o câmbio, mas a taxa de juros, que, se diminuída, poderia, ao evitar a entrada de capitais especulativos, impedir a apreciação do câmbio, ajudando não somente as exportações, como também o fortalecimento do mercado interno, avançando em questões redistributivas, de emprego e de salário.

Centrar o crescimento econômico na política cambial, e não na política industrial, revela continuidade no paradigma tecnológico e na estrutura produtiva atuais, perpetuando o problema estrutural da estagnação da produtividade

27 A preocupação de Oreiro com a possível saída da inflação de sua meta nos mostra sua visão sobre o tipo de política a ser adotada para reduzi-la, sem, é claro, usar da valorização cambial: "O problema é que o espaço existente hoje para uma nova rodada de apreciação da taxa de câmbio é zero. A estagnação da produção industrial e da exportação de manufaturados desde 2010, em conjunto com o crescimento do déficit em conta corrente que se aproxima do patamar de $4 \%$ do PIB, mostram, de forma inequívoca, que a taxa de câmbio se encontra sobre-valorizada. Isso significa que nos próximos anos um ajuste no sentido de uma taxa de câmbio mais desvalorizada será inevitável. Dessa forma, o canal da taxa de câmbio não estará disponível para fazer uma "desinflação sem dor'. Não restará alternativa que não o 'purgatório' do aumento do desemprego" (OREIRO, 2014c). 
brasileira. A não preocupação com a mudança estrutural fica clara na defesa da centralidade da taxa de câmbio para o novo desenvolvimentismo, pois para seus defensores a adoção de uma taxa de câmbio de equilíbrio industrial viabilizaria a competitividade internacional de empresas nacionais que utilizam tecnologia no estado da arte mundial (BRESSER-PEREIRA; GALA, 2010).

Nesse sentido, como forma de síntese, a Figura 1 apresenta os principais elementos que deveriam estar presentes em uma estratégia de desenvolvimento para a superação do atraso no século XXI.

Figura 1 - Elementos basilares da estratégia de desenvolvimento para o século XXI

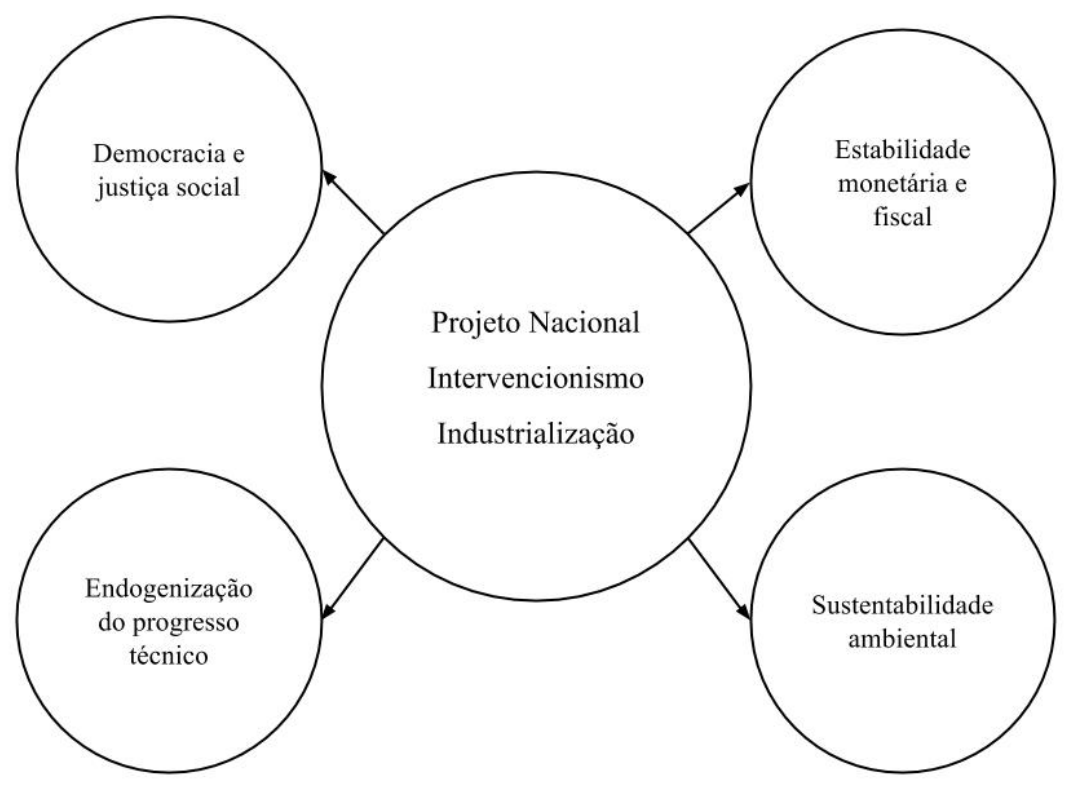

Fonte: Elaboração própria.

Em primeiro lugar, considera-se ainda relevante a manutenção do core do conceito desenvolvido por Fonseca (2014). Isso porque se acredita na importância do papel do Estado e da indústria para a instituição de uma estratégia de catching up (projeto nacional). Vários estudos contemporâneos corroboram a importância do papel do Estado e da indústria na trajetória de desenvolvimento das nações (CHANG, 1999, 2004; CHANG; EVANS, 2000; RODRIK, 2006). Ao se analisar trajetórias de desenvolvimento capitalista de sucesso, percebe-se que tais sempre contaram com a presença do Estado como ator estratégico, o qual cumpriu com variável intensidade diversas funções estruturantes e reguladoras da atividade econômica (CHANG, 2004; GERSCHENKRON, 1973). Com isso, sociedades atrasadas que lograram superar sua defasagem tecnológica e alcançar elevados níveis 
de produtividade e renda per capita fizeram do Estado seu principal instrumento estratégico.

Dessa forma, destaca-se a importância do ambiente histórico e social na análise de trajetórias capitalistas (ZYSMAN, 1994). Dada a heterogeneidade institucional de cada nação, e de acordo com determinado período histórico das relações econômicas internacionais, percebe-se a ocorrência de diversos processos ou "tipos" de desenvolvimento econômico. Portanto, o que a história econômica ensina é que justamente existe diversidade de estratégias de desenvolvimento, e não um modelo único. O emparelhamento (catching up) por parte de países retardatários com as nações capitalistas já desenvolvidas é um processo sujeito a variantes históricas, que se prendem à estrutura social pretérita à industrialização e às condições das relações econômicas internacionais na etapa histórica do capitalismo mundial (OLIVEIRA, 2003), além das possibilidades concretas de ingresso a novos paradigmas tecnológicos.

Faz-se mister, portanto, interromper o processo de desindustrialização precoce brasileiro, bem como incitar a mudança da estrutura produtiva nacional. Conforme identifica Arend (2014), a indústria brasileira desde a década de 1990 apresenta elevada inércia em sua estrutura produtiva e no seu comércio exterior. Em grande medida, também se pode afirmar que a composição estrutural da indústria brasileira contemporânea deriva da última política industrial de grande magnitude implementada no país: o II PND. Essa política industrial concretizou-se na década de 1980, e, desde esse período, o Brasil revela extrema dificuldade de diversificar sua estrutura industrial em direção à incorporação dos novos setores emblemáticos da revolução tecnológica que irrompeu exatamente nesse período (microeletrônica). Tais setores industriais foram decisivos para o processo de rejuvenescimento industrial e, consequentemente, pelo salto de produtividade das economias que tiveram capacidade adaptativa para ingressar nesse novo paradigma tecnoprodutivo (AREND; FONSECA, 2012).

Segundo Arend (2014), a economia brasileira apresenta ínfima inserção de sua indústria nas novas tecnologias ancoradas na microeletrônica, capazes de acarretar elevação da produtividade nacional de forma sustentada. É o grupo industrial que apresenta a menor participação percentual na estrutura produtiva, o menor grau de adensamento produtivo e a menor corrente de comércio. Os motores do investimento e do crescimento nacional, há décadas, são os grupos industriais relacionados a commodities agroindustriais e à indústria representativa do antigo padrão fordista de produção, esta também limitada pela baixa potencialidade futura de desencadear inovações tecnológicas capazes de proporcionar elevação sustentada da produtividade. Logicamente, não existe uma receita pronta para o rompimento da inércia produtiva brasileira. $\mathrm{O}$ que deve ficar claro é que estratégias de desenvolvimento carecem de inovações institucionais, o que não 
exclui a imitação de arranjos construídos por outros países em vias de superação do atraso. Entretanto, o desenvolvimento econômico se configura e deriva de estratégias domésticas, e não do mercado mundial (RODRIK, 2002).

Nesse mesmo pensamento, e fazendo uma ligação entre a importância da indústria e a sustentabilidade ambiental, recentemente Carlota Pérez (2010) propõe uma estratégia para dinamizar o desenvolvimento da América Latina aproveitando as oportunidades específicas do contexto atual (ascensão dos preços das matérias-primas a partir de 2000) e as vantagens que oferece a região (recursos naturais): trata-se do desenvolvimento criativo de indústrias de processamento de recursos naturais como forma de superação do atraso, redução da pobreza e desenvolvimento do mercado interno. Segundo a autora,

La adquisición de capacidades en las industrias basadas en recursos naturales, vinculadas a la biotecnología y a la ciencia de los materiales, tiene la ventaja de preparar el terreno para el posicionamiento adecuado en las tecnologías que hoy se vislumbran como probables protagonistas de la próxima revolución tecnológica: biotecnología, nanotecnología, bioelectrónica y nuevos materiales (PÉREZ, 2010, p. 124).

Por fim, a questão crucial é que uma estratégia de desenvolvimento no século XXI deve incorporar outros elementos que não necessariamente estavam presentes no século XX. Se o desenvolvimentismo no século XX ancorava-se, em maior ou menor grau, na concentração de renda e no autoritarismo (1964-1985), e/ou na aceleração inflacionária e no endividamento público (Plano de Metas do governo JK e II PND), o desenvolvimentismo contemporâneo não pode (ou não deveria) valer-se desses artifícios, o que o torna mais problemático de instituir-se. Estabilidade monetária e democracia com justiça social são valores já enraizados na sociedade brasileira. Tanto o social-desenvolvimento, quanto o novo desenvolvimentismo são enfáticos ao defender tanto a estabilidade monetária e fiscal quanto a democracia e a justiça social. Todavia, o avanço em ambos os projetos nacionais deveria se concentrar na incorporação de elementos que garantissem a busca por endogeneizar o progresso técnico, na esteira de um novo paradigma tecnoeconômico sustentável (PÉREZ, 2010).

\section{Considerações Finais}

Por meio do que se entende como desenvolvimentismo, foi visto que há estratégias presentes na academia que sequer se enquadram no conceito. Para poderem ser caracterizadas como desenvolvimentistas, as estratégias precisam conter os três pilares básicos do núcleo do conceito: projeto nacional, intervencionismo e industrialização. Apesar de todas por si só poderem ser consideradas projetos nacionais, o resultado quanto às outras variáveis difere bastante. $\mathrm{O}$ grau de 
intervencionismo é muito maior no caso do social-desenvolvimentismo, no qual o Estado é um agente indutor do investimento. No novo desenvolvimentismo o capital privado tem participação maior e o grau de intervenção estatal está mais relacionado ao controle dos preços macroeconômicos. Já a corrente da Casa das Garças defende uma eficiência econômica que não vai ao encontro da intervenção estatal, transparecendo a ideia de um projeto nacional que promova uma nova rodada de liberalização comercial, tal qual imaginada e praticada nos anos 1990. Quanto à industrialização, seria o setor estratégico tanto do social, quanto do novo desenvolvimentismo. Já para o modelo de integração de Bacha, o foco não parece estar no setor industrial, mas na criação de uma atmosfera ideal para o desenvolvimento de atividades lucrativas conectadas ao comércio mundial, sejam elas a exportação de manufaturados, serviços ou commodities.

Neste artigo mostrou-se também que as duas estratégias desenvolvimentistas em debate têm prós e contras e que, para o benefício do objetivo maior do desenvolvimento nacional, alguns de seus pontos deveriam ser mesclados, obtendo-se uma evolução na abordagem ao se destacar a problemática das mudanças tecnológicas e institucionais. Reconhece-se que o Brasil deve se valer de sua demanda interna, mas não unicamente. Deve, sim, se inserir competitivamente no exterior, mas sem que isso signifique dar incentivos ao capital em detrimento do proletariado do país, ou mesmo implementar medidas de cunho austero que malogrem os ganhos reais dos trabalhadores. Já foi observado, não faz muito tempo, que realizar crescimento econômico à custa dos menos abastados é qualquer coisa que não o desenvolvimento econômico. Vale lembrar as palavras de Celso Furtado, realizar "transmutação dos meios em fins". Os fins deveriam começar a ficar mais claros para todos - como o bem-estar social e a liberdade, no sentido de Amartya Sen. O debate sobre os meios de obtê-los há de se engrandecer se voltar àquele que melhor pensou nossa realidade.

Por fim, cabe destacar que o Brasil conseguiu mudar sua posição no sistema interestatal, de condição periférica para semiperiférica (ARRIGHI, 1997), a partir da década de 1930, com políticas desenvolvimentistas conscientes pró-industrialização. Aquele período histórico também foi caracterizado pela grande depressão, crise do laissez faire e transição de hegemonia econômica mundial (da britânica para a norte-americana). O período atual apresenta semelhanças com o anterior: crise da ideologia neoliberal, estagnação nos países avançados, declínio econômico da potência hegemônica (Estados Unidos) e retomada de políticas desenvolvimentistas em países periféricos (AREND, 2013). Seria talvez chegado o momento de uma nova mudança de posição do Brasil no sistema interestatal, de condição semiperiférica para núcleo orgânico. 


\section{Referências}

AREND, M. A industrialização do Brasil ante a nova divisão internacional do trabalho. In: CALIXTRE, A. B.; BIANCARELLI, A. M.; CINTRA, M. A. M. (Org.). Presente e futuro do desenvolvimento brasileiro. Brasília, DF: Ipea, 2014. Cap. 10. p. 375-421.

. O Brasil e o longo século XX: condicionantes sistêmicos para estratégias nacionais de desenvolvimento. In: VIEIRA, R. (Org.). Brasil, China e EUA na economia política do sistemamundo capitalista. São Paulo: Cultura Acadêmica, 2013. Cap. 5. p. 135-172.

. Revoluções tecnológicas, finanças internacionais e estratégias de desenvolvimento: um approach neo-schumpeteriano. Ensaios FEE, v. 33, n. 2, p. 363-396, nov. 2012.

AREND, M.; FONSECA, P. C. D. Brasil (1955-2005): 25 anos de catching up, 25 anos de falling behind. Revista de Economia Política, v. 32, n. 1, p. 33-54, 2012.

ARRIGHI, G. A ilusão do desenvolvimento. Petrópolis: Vozes, 1997.

BACHA, E. L. Integrar para crescer: o Brasil na economia mundial. 2013. (Texto para discussão IEPE/CdG, n. 27). Disponível em: < http://iepecdg.com.br/uploads/ texto/130912BACHAFNAC.pdf>. Acesso em 03 set. 2015.

BACHA, E; DE BOLLE, M. O futuro da indústria no Brasil: desindustrialização em debate. Rio de Janeiro: Civilização Brasileira, 2013.

BANCO CENTRAL DO BRASIL. Série histórica do balanço de pagamentos - $6^{a}$ edição do Manual de balanço de pagamentos e posição de investimento internacional (BPM6). Disponível em: <http://www.bcb.gov.br/?SERIEBALPAG> . Acesso em: 03 set. 2015.

BASTOS, P. P. Z. A economia política do novo-desenvolvimentismo e do social desenvolvimentismo. Economia e Sociedade, Campinas, v. 21, n. especial, p. 779-810, dez. 2012.

BIELSCHOWSKY, R. Estratégia de desenvolvimento e as três frentes de expansão no Brasil: um desenho conceitual. Economia e Sociedade, Campinas, v. 21, n. especial, p. 729-747, dez. 2012.

BONELLI, R.; PESSÔA, S.; MATOS, S. Desindustrialização no Brasil: fatos e interpretação. In: BACHA, E; DE BOLLE, M. O futuro da indústria no Brasil: desindustrialização em debate. Rio de Janeiro: Civilização Brasileira, 2013. Cap. 2. p. 45-80.

BRESSER-PEREIRA, L. C. A rede desenvolvimentista e o novo desenvolvimentismo. Intervenção no seminário Desenvolvimento e Crise Global: Impactos no Brasil e na América Latina, Rede Desenvolvimentista, Unicamp, 08 maio 2012a.

Baixo crescimento, ideologia e pensamento. Folha de São Paulo. 17 dez. 2012d. Disponível em: <http://www.bresserpereira.org.br/Articles/2012/78.Baixo_crescimento_ ideologia_pensamento.pdf $>$. Acesso em: 03 set. 2015.

. Bresser-Pereira website. 2015. Disponível em: <http://bresserpereira.org.br/> . Acesso em: 03 set. 2015.

MOREIRA, A. G.; AREND, M. Que estratégia de desenvolvimento seguir? O Debate... 
BRESSER-PEREIRA, L. C. Diálogo com a Unicamp sobre novo desenvolvimentismo. 13 set. 2012d. Disponível em: <http://bresserpereira.org.br/view.asp?cod=5094> . Acesso em: 03 set. 2015.

. Do antigo ao novo desenvolvimentismo na América Latina. In: PRADO, L. C. D. (Org.). Desenvolvimento econômico e crise: ensaios em comemoração aos 80 anos de Maria da Conceição Tavares. Rio de Janeiro: Contraponto, 2012b. Cap. 2. p. 27-66.

. Macroeconomia da estagnação. São Paulo: Editora 34, 2007. jun. 2012c.

Os três ciclos da sociedade e do estado. Perspectivas, São Paulo, v. 41, p. 13-51, jan./

. Taxa de câmbio e doença holandesa. Valor Econômico. 19 fev. 2013. Disponível em: <http://www.bresserpereira.org.br/articles/2013/13.02.Valor-Taxa_de_cambio.pdf $>$. Acesso em: 03 set. 2015.

. Uma escola de pensamento keynesiano-estruturalista no Brasil? Revista de Economia Política, v. 31, n. 2, p. 305-314, abr.jun. 2011.

BRESSER-PEREIRA, L. C.; GALA, P. Macroeconomia estruturalista do desenvolvimento. Revista de Economia Política, v. 30, n. 4, p. 663-686, out./dez. 2010.

CARNEIRO, R. M. Velhos e novos desenvolvimentismos. Economia e Sociedade, Campinas, v. 21, n. especial, p. 749-778, dez. 2012.

CAVALCANTE, L. R.; NEGRI, F. Produtividade no Brasil: uma análise do período recente. 2014. (Texto para discussão IPEA, n. 1955).

CHANG, H. Chutando a escada: a estratégia do desenvolvimento em perspectiva histórica. São Paulo: Unesp, 2004.

. The economic theory of the developmental state. In: WOO-CUMINGS, M. The developmental state. New York: Cornell University Press, 1999. Cap. 6. p. 182-199.

CHANG, H.; EVANS, P. The role of institutions in economic change. Aug. 2000. (Paper for the meeting of the "Other Canon" group. Oslo).

CORDEIRO, R. M. Os projetos de desenvolvimento do Brasil contemporâneo. Revista de Economia Política, v. 34, n. 2, p. 230-248, abr.jun. 2014

CUNHA, A. M.; BRITTO, G. When development meets culture: the contribution of Celso Furtado in the 1970s. In: ANNUAL CONFERENCE OF THE EUROPEAN SOCIETY FOR THE HISTORY OF ECONOMIC THOUGHT, 15., 2011, Istambul. Proceedings... Istanbul: ESHET, 2011.

ERBER, F. As convenções do Desenvolvimento no Governo Lula: um ensaio de economia política. Revista de Economia Política, São Paulo, v. 31, n. 1, p. 31-55, jan.-mar. 2011.

FIORI, J. L. De volta a questão da riqueza das nações. IN: FIORI, J. L. (Org). Estado e moedas no desenvolvimento das nações. Rio de Janeiro: Vozes, 1999. Introdução. p. 11-46. 
FONSECA, P. C. D. Desenvolvimentismo: a construção do conceito. In: CALIXTRE, A. B.; BIANCARELLI, A. M.; CINTRA, M. A. M. (Org.). Presente e futuro do desenvolvimento brasileiro. Brasília, DF: Ipea, 2014. Cap. 1. p. 29-78.

FRANCO, G. É preciso retomar a agenda de reformas [entrevista]. In: Instituto de Estudos de Política Econômica - Casa das Garças, Rio de Janeiro, 2014. Disponível em: < http://iepecdg. com.br/?acao $=$ reportagensEreportagem $=662>$. Acesso em: 03 set. 2015.

FURTADO, C. Criatividade e dependência na civilização industrial. São Paulo: Círculo do Livro, 1978.

. O mito do desenvolvimento econômico. Rio de Janeiro: Paz e Terra, 1974.

GERSCHENKRON, A. Atraso económico e industrialización. Barcelona: Ariel, 1973.

INSTITUTO DE ESTUDOS DE POLÍTICA ECONÔMICA - CASA DAS GARÇAS. 2015. Disponível em: <http://iepecdg.com.br>. Acesso em: 03 set. 2015.

KUPFER, J. P. Dilemas: Que diferença faz. Época Negócios, Rio de Janeiro, n. 85, p.68-101, mar. 2014.

MACROECONOMIA ESTRUTURALISTA DO DESENVOLVIMENTO. 2015. Disponível em: <http://macrododesenvolvimento.wordpress.com/>. Acesso em: 03 set. 2015.

MOLLO, M. L. R. O debate desenvolvimentista: reflexões sobre alternativas desenvolvimentistas marxistas. Disponível em: <http://www.bresserpereira.org.br/terceiros/ novo\%20desenvolvimentismo/14.01.Mollo-Debate_desenvolvimentista-REP.pdf $>$. Acesso em: 23 maio 2014.

MOLLO, M. L.; FONSECA, P. C. D. Desenvolvimentismo e novo-desenvolvimentismo: raízes teóricas e precisões conceituais. Revista de Economia Política, v. 33, n. 2 (131), p. 222-239, 2013.

NOGUEIRA, L. A. "O Brasil precisa perseguir uma inflação de 3\%". Entrevista com Edmar Bacha, economista e ex-presidente do BNDES. Isto É Dinheiro, 27 dez. 2013. Disponível em: $<$ http:/www.istoedinheiro.com.br/noticias/economia/20131227/brasil-precisa-perseguiruma-inflacao/8440.shtml>. Acesso em: 13 maio 2014

O POVO ONLINE. Economista da FGV confirma trabalho com Aécio. 2014. Disponível em: <http://www.opovo.com.br/app/politica/ae/2014/04/02/noticiaspoliticaae,3230075/ economista-da-fgv-confirma-trabalho-com-aecio.shtml>. Acesso em: 03 set. 2015.

OLIVEIRA, C. A. B. Processo de industrialização: do capitalismo originário ao atrasado. São Paulo: Editora da Unesp, 2003.

OREIRO, J. L. A armadilha juros-câmbio: a continuidade do desequilíbrio macroeconômico brasileiro. 2014a. Disponível em < http://jlcoreiro.wordpress.com/2014/04/04/a-armadilhajuros-cambio-a-continuidade-do-desequilibrio-macroeconomico-brasileiro $>$. Acesso em: 03 set. 2015. 
OREIRO, J. L. A moderação salarial, inflação e a competitividade da indústria. 2013a. Disponível em: <https://jlcoreiro.wordpress.com/2013/05/07/a-moderacao-salarial-inflacaoe-a-competitividade-da-industria/> . Acesso em: 03 set. 2015.

Comentários de Eleutério Prado ao meu artigo "A Armadilha Juros-Câmbio: a continuidade do desequilíbrio macroeconômico brasileiro". 2014b. Disponível em: <https:// jlcoreiro.wordpress.com/2014/04/18/comentarios-de-eleuterio-prado-ao-meu-artigo-aarmadilha-juros-cambio-a-continuidade-do-desequilibrio-macroeconomico-brasileiro $>$. Acesso em: 03 set. 2015.

. É viável uma meta de inflação de 3\% para 2019? 2014c. Disponível em: < https:// jlcoreiro.wordpress.com/2014/05/13/e-viavel-uma-meta-de-inflacao-de-3-para-2019-portalvamos-ao-debate-13052014>. Acesso em: 03 set. 2015.

. Estratégia de crescimento divide heterodoxos. 2013b. Disponível em: <https://jlcoreiro. wordpress.com/2013/10/24/estrategia-de-crescimento-divide-heterodoxos-vlor-24102013>. Acesso em: 03 set. 2015.

. José Luis Oreiro - Economia, Opinião e Atualidades. 2015. Disponível em: < http:// jlcoreiro.wordpress.com >. Acesso em: 03 set. 2015.

- Novo-desenvolvimentismo, crescimento econômico e regimes de política macroeconômica. Estudos Avançados, v. 26, n. 75, p. 29-40, 2012.

OREIRO, J. L.;. BASÍLIO, F. A. C.; SOUZA, G. J. G. Acumulação de capital, taxa real de câmbio e catching-up: teoria e evidência para o caso brasileiro. 2013. Disponível em <http:// eesp.fgv.br/sites/eesp.fgv.br/files/file/Jose\%20Luiz\%20Oreiro\%20forum\%202013.pdf>. Acesso em: 17 mar. 2014.

PAULA, J. A. Celso Furtado, desenvolvimento e transformação social. In: D'AGUIAR, R. F. (Org.). Celso Furtado e a dimensão cultural do desenvolvimento. Rio de Janeiro: Centro Internacional Celso Furtado, 2013. Cap. 1. p. 13-49. (E-paper).

PEREZ, C. Dinamismo tecnológico e inclusión social en América Latina: una estrategia de desarrollo productivo basada en los recursos naturales. Revista de la Cepal, n. 100, Apr. 2010.

PRADO, E. F. S. O mau humor do "mercado". 17 abr. 2014. Disponível em: < https:// eleuterioprado.wordpress.com/2014/04/17/o-mau-humor-do-mercado >. Acesso em: 03 set. 2015 .

RODRIK, D. Growth Strategies. In: AGHION, P.; DURLAUF, S. (Ed.). Handbook of economic growth. Amsterdam: Elsevier North-Holland, 2002. v. 1a. Cap. 14. p. 967-1014.

. Industrial development: stylized facts and policies. Harvard University, Aug. 2006.

The real exchange rate and economic growth. Brookings Papers on Economic Activity, Sept. 2008. Disponível em: <http://www.brookings.edu/ /media/Files/Programs/ ES/BPEA/2008_fall_bpea_papers/2008_fall_bpea_rodrik.pdf $>$. Acesso em: 9 set. 2015.

SALOMÃO, A.; NEDER, V. "Para escapar do pibinho o caminho é a abertura" diz Edmar Bacha. 2014. Disponível em: <http://economia.estadao.com.br/noticias/geral,para-escapardo-pibinho-o-caminho-e-a-abertura-diz-edmar-bacha,179704e> . Acesso em: 03 set. 2015. 
SINGER, A. Realinhamento, ciclo longo e coalizões de classe. Revista de Economia da PUCSP, n. 4, ano 2, p. 37-66, jul./dez. 2010.

ZYSMAN, J. How institutions create historically rooted trajectories of growth. Industrial and Corporate Change, v. 3, n. 1, p. 243-283, 1994.

Rebido em: 27/05/2014. Aceito em: 04/02/2015. 